\title{
「レプトスピラ」ノ病原性站二種屬二 關スル研究
}

第 五 報

（昭和 13 年 9 月 22 日受付）

東京帝國大學傳染病研究所第入研究部(部長 高木教授)

研究生新家偕 三

第二節「七日熱及「ワイル」兩性狀ヨ示ス所謂中間型

「七日熱」こ就テ

前節，實驗二於テ分離 シ得タル「七日熱」No.992B 及 No. 997B. 兩株ハ. 出發株 「七日熱」性狀二變異き生涂カモ「七日熱」ト「ワイル」トノ中間性狀キ示シ。而シテ No. 997 B株八「七日熱性狀二近ク「ワィル」二遠キ性狀キ示シ No. 992 B株ハ「七日

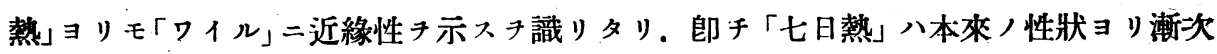
「ワイル」樣性狀二推移動向ス。文獻キ糺邓ル二上記特殊性狀若シクハ之二類似スル性 狀キ示ス「七日熱」關ス几記載キ見ズ。本特殊性狀キ示ス「七日熱」就テ其性狀キ更 二追及七ント欲シ. 一ッハ毒性二關シ。一ツハ免疫血清學的性狀二關シ. 兩方面ヨy 探究セントセリ。然ル二弱毒株「七日熱」其毒力極メラ不安定ナルノミナラズ。毒力 八强弱八 Lp ノ生活要的適否ニョリテ直チ二相違キ示シ. 毒力ノ强弱ハ「七日熱」限 リソノ急疫血清學的性狀二相違キ示ス實證アルニ鑑え 。本中間型「七日熱」No. $992 \mathrm{~B}$ No. 997B兩株ハ何レモ分離培養シ得タル第 1 代株キ以テ毒性キ檢スルト同時二.免度

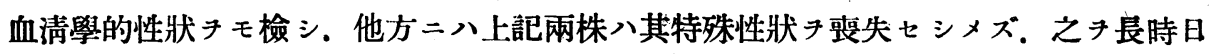
保持シ得ルヤ否ヤハ最モ疑問トスル所ナルキ以テ.上記兩株ノ培養第 1 代株チ以テ抗

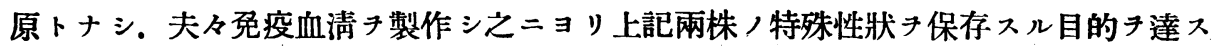
ルト共二. 兩株ノ抗體產生性能ヨ檢シテ爾後ノ研究二便㿽卜遺漏ナカラン事ヨ期シタ リ。唒培養世代き累加シテ時々其毒性泣二免疫血清學的性狀テ檢シ。是等兩株が出發 株ノ「七日熱」性狀二復歸スルヤ否ヤキ检シタリ。

\section{芦一項 中間型「七日鰠」毒性}


中間型性狀丹示ス No. 992 B. No. 997 B兩株ノ培養第 1 代株ノ毒性ォ「マウス」站

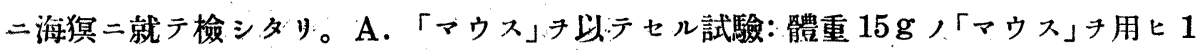
群八觀察用トシ。他ノ群入病材用トナス。培養 1 c.c. キ「マウス」腹腔內二接種シ爾後時 間的二腹膑液內 $\mathrm{Lp}$ ，消長 檢シ。病材組八適時撲殺シテ累代通過ノ成否檢ス。以 上成績. (1) No. 992B株「マウス」腹腔液內二於テ $\mathrm{Lp}$ ハ4 日間生活スルキ認メ. 累 代通過八接種後 24 時間ニシテ腹腔液內 $\mathrm{Lp}$ (卅) 時ハ成立シ。 48 時間 (\#) 時く於テハ 成立七ズ. 72 時間 $(+)$ 時モ亦成立七ズ。(2) No. $997 \mathrm{~B}$ 株「マウス」腹腔液內二 Lp 八 4 日間生活スルキ認メ。累代通過八接種後 24 時間二於テ $\mathrm{Lp}$ 數 (卅) 時八成立ス. 然 レドモ爾後ノ時間二於テハ成立セズ(實驗表省略)。

B. 海猽キ以テセル試驗：體重 $150 \mathrm{~g}$ ，海猽キ選ビ前處置タ施サズ比較的大量 5 c.c.

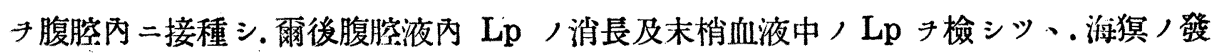

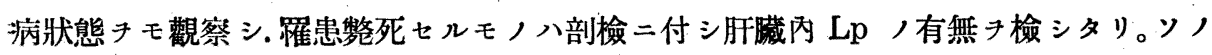
成績八. (1) No. 992B株. 接種後 9-11 日ニシテ定型的症狀ノ下二罹患整死シ（2） No. 997B株. 接種後 12-14 日ニシテ定型的症狀 下二罹患整死七リ。(實驗表省略)

\section{第二項 中間型「七日熱」ヨ抗原トシタル免疫血清二就テ}

（I）體重 $2.500 \mathrm{~g}$ ，白色健康家鬼使用シ. 抗原ハNo. $992 \mathrm{~B}$ ，培養第 1 代及第 3 代, 生菌テ以テセリ。ソ/使用量ハ 2 c.c. 5 c.c. . 10c.c.尹何レモ 7 日ノ間隔キ以テ耳

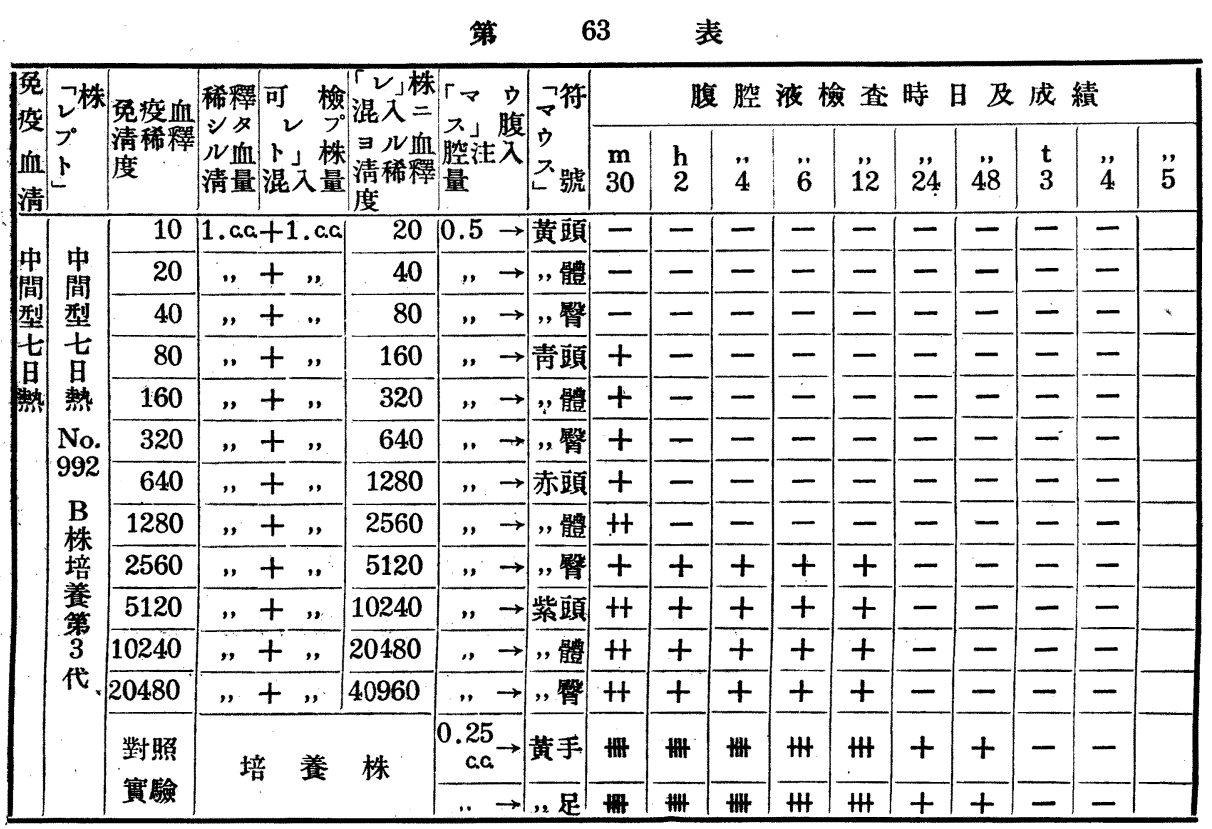




\begin{tabular}{|c|c|c|c|c|c|c|c|c|c|c|c|c|c|c|c|}
\hline \multirow{2}{*}{ 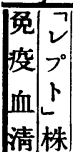 } & \multirow{2}{*}{$\begin{array}{l}\text { 免疫血 } \\
\text { 清稀粆 } \\
\text { 度 }\end{array}$} & \multirow{2}{*}{$\begin{array}{l}\text { 稀釋 シ } \\
\text { 血 } \\
\text { 清量 }\end{array}$} & \multirow{2}{*}{ 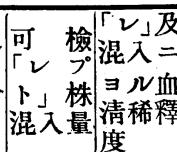 } & \multirow{2}{*}{ 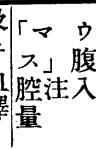 } & \multirow{2}{*}{ 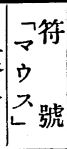 } & \multicolumn{10}{|c|}{ 腹脘 液 檢 查時 日 及成 績 } \\
\hline & & & & & & $\begin{array}{l}\mathrm{m} \\
30\end{array}$ & & $\ddot{4}$ & $\ddot{6}$ & $\ddot{12}$ & $\ddot{24}$ & $\ddot{48}$ & $\begin{array}{l}\mathbf{t} \\
3\end{array}$ & & $\ddot{5}$ \\
\hline \multirow{14}{*}{ 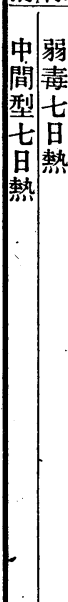 } & 10 & 1.c.c. +1 .c.c. & 20 & $0.5 \rightarrow$ & 黄頭 & 一 & - & 一 & 一 & - & 一 & - & 一 & - & \\
\hline & 20 & $"+$, & 40 & $" \rightarrow$ & , 體 & 一 & - & - & - & - & - & - & 一 & 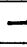 & \\
\hline & 40 & $"+$, & 80 & $" \rightarrow$ & ,能 & - & - & - & - & - & - & - & - & 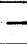 & \\
\hline & 80 & ",+ & 160 & ". $\rightarrow$ & $\overline{\mathrm{F}} \overline{\mathrm{F}}$ & 一 & - & - & - & - & - & - & - & - & \\
\hline & 160 & $"+$, & 320 & $" \rightarrow$ & ,, 體 & - & - & - & - & - & - & - & - & - & \\
\hline & 320 & $"+$, & 640 & $" \rightarrow$ & ,臂 & - & $\div$ & - & - & - & - & - & - & - & \\
\hline & 640 & 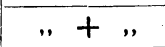 & 1280 & $" \rightarrow$ & 赤頭 & - & - & - & - & - & - & - & - & 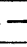 & \\
\hline & 1280 & $"+"$ & 2560 & $\Rightarrow \rightarrow$ & , , 體 & - & - & - & - & - & - & - & - & & \\
\hline & 2560 & $"+$, & 5120 & $", \rightarrow$ & , 睯 & + & - & - & - & - & - & - & - & 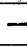 & \\
\hline & 5120 & $"+"$ & 10240 & $" \rightarrow$ & 紫頭 & + & - & - & - & - & - & - & 一 & 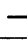 & \\
\hline & 10240 & $"+$, & 20480 & $" \rightarrow$ & , 體 & + & - & - & - & - & 一 & - & - & & \\
\hline & 20480 & $"+$, & 40960 & $", \rightarrow$ & ,,慰 & + & - & - & - & - & - & - & - & & \\
\hline & 對照 & 培 & 株 & $\begin{array}{r}0.25 \\
\text { c.c. }\end{array}$ & 黄手 & 册 & \# & 册 & $\mathrm{HH}$ & H & + & + & - & & \\
\hline & 筫驗 & & & . $\rightarrow$ & , 足 & 册 & $\#$ & 册 & \# & 世 & + & + & - & $=$ & \\
\hline
\end{tabular}

第

65 表

\begin{tabular}{|c|c|c|c|c|c|c|c|c|c|c|c|c|c|c|c|}
\hline \multirow{2}{*}{ 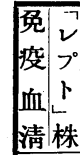 } & \multirow{2}{*}{$\begin{array}{l}\text { 免疫血 } \\
\text { 清稀釋 } \\
\text { 度 }\end{array}$} & \multirow{2}{*}{\multicolumn{2}{|c|}{ 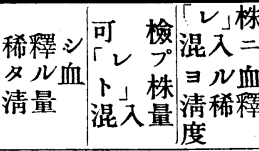 }} & \multirow{2}{*}{ 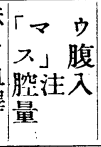 } & \multirow{2}{*}{$\begin{array}{l}\text { マ符 } \\
\text { ウ } \\
\text { ス號 }\end{array}$} & \multicolumn{10}{|c|}{ 腹腔液檢查時 日 及成績 } \\
\hline & & & & & & $\begin{array}{l}\mathrm{m} \\
30\end{array}$ & & 4 & $\ddot{6}$ & 12 & $\ddot{24}$ & 48 & $\begin{array}{l}\mathbf{t} \\
3\end{array}$ & $\ddot{4}$ & $\ddot{5}$ \\
\hline \multirow{14}{*}{ 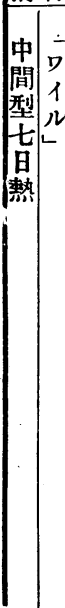 } & 10 & 1.c.c. +1 . c.c. & 20 & $0.5 \rightarrow$ & 黃頭 & - & - & - & - & - & - & - & - & - & - \\
\hline & 20 & $",+$. & 40 &,$\quad \rightarrow$ & , 體 & - & - & 一 & - & - & - & - & 一 & - & - \\
\hline & 40 & . + & 80 &,$\quad \rightarrow$ & , 撤 & tt & - & - & - & - & - & - & - & - & - \\
\hline & 80 & $.1+$ & 160 &,$\quad \dot{\rightarrow}$ & 靑頭 & tt & + & - & 一 & - & - & - & - & - & - \\
\hline & 160 & $"+$ & 320 & $" \rightarrow$ & ,, 體 & tt & $T$ & + & $T$ & + & - & - & - & - & - \\
\hline & 320 & , + & 640 & $" \rightarrow$ & , 繁 & tt & $T$ & + & $T$ & + & + & - & + & - & - \\
\hline & 640 & $"+$ & 1280 &,$\quad \rightarrow$ & 赤頭 & $\mathrm{HH}$ & + & + & + & + & + & + & + & - & 一 \\
\hline & 1280 & $"+n$ & 2560 &,$\quad \rightarrow$ & , 體 & $\mathrm{HH}$ & t+ & + & + & + & $f$ & + & + & + & - \\
\hline & 2560 & ".+ & 5120 & . $\rightarrow$ & , 智 & W & t+ & + & + & + & + & + & + & + & - \\
\hline & 5120 &..+ & 10240 & $" \rightarrow$ & 紫頭 & HH & $t+$ & + & 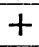 & + & 1 & + & 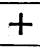 & + & - \\
\hline & 10240 & $"+n$ & 20480 & $\because \rightarrow$ & , 體 & HI & t+ & tt & $T$ & + & + & + & $T$ & + & 一 \\
\hline & 20480 & $"+$, & 40960 &.$\quad \rightarrow$ & ,, 鳘 & $\mathrm{H}$ & $t+$ & $+t$ & & + & + & + & & + & 一 \\
\hline & 對照 & 培 & \multirow[t]{2}{*}{ 株 } & $\underset{\mathrm{a} . \mathrm{G}}{0.25} \rightarrow$ & 黄手 & 册 & 冊 & 冊 & HIt & 册 & HH & tt & + & + & - \\
\hline & 實驗 & & &..$\rightarrow$ & , 足 & Hith & 册 & 册 & 册 & 册 & $\mathrm{HH}$ & + & + & + & - \\
\hline
\end{tabular}

靜脈內二注射七リ。最終抗原注射後 3 週間キ經テ全採血シテ血清テ分離シ. 石炭酸チ 加へズ水宝二貯臟入。以上ノ如ク本血清八抗原トシタルNo. 992B株ノ培養第 1 代 そチ以テ製作スル目的ナリシガ. 抗原量ニ不足キ生ジ巳ムナク培養第 3 代チモ使用七 
リ。No. 997 B株, 免疫血清八. 免疫過程二於テ動物整死シタルニョリ已ムナク中止 セリ。(II) 本血清二對シ.（1)抗原トシタル No. 992B株培養第 3 代.（2)弱毒株「七 日熱」（3）「ワイル」以上 3 種ノ培養キ以テ「マウス」腹膑內溶菌反應キ檢シタリ。（面） 實驗成績 (第 63-65 表)。（1）No. 992B. 培養第 3 代實驗後 30 分ニシテ 80 倍 2 時間 ニシテ 2560 倍. 24 時間ニシテ 40960 倍二陽性. (2) 弱毒株「七日熱. 實驗後 30 分二 シテ 2560 倍. 2 時間ニシテ 40960 倍二陽性。（3）「ワイル」一實驗後 30 分ニシテ 40 倍 2 時間ニシテ 80 倍. 4 時間 160 倍. 24 時間 320 倍二陽性。以上ノ成績ニョリ本血清 八「七日熱」ト區別シ難キ性狀キ示ス. 之キ抗原トシタル No. 992B株ノ性狀ト比較シ

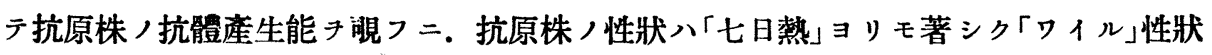
二近線性ォ示スニ反シ. 本血清ガ上記性狀ォ示スハ. 抗體產生能二於テ矛盾ノ存スル 觀チ呈ス。然レドモ本血清製作二當リ。第 1 回及第 2 包/抗原ハNo. 992 B培養第 1 代キ以テシタル二. 第 3 回ノ抗原八後述スル如ク既二出發株ノ「七日熱」性狀二復歸シ テ「ワイル」二共通スル性狀ョ雯失シタル培養第 3 代チ使用シタリ。故二本血清ノ示ス 性狀八抗原ノ性狀二相一致シ。本抗原ノ示ス抗體産生能モ亦何等矛盾ノ存ゼザルコト フ確メ得タリ。

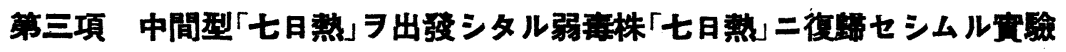

中間型性狀チ示ス No. 992B 及 No. 997B 兩株ガ出發シタル原株ノ「.七日熱」復 歸スルヤ否ヤキ檢スル䉆メ二，培養世代チ累加シ適時毒性端二血清學的性狀キ檢シタ

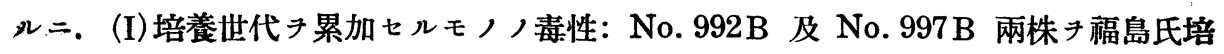
地二培飬シ第 3 代ノ毒性キ「マウス」及海猽キ以テ檢シタリ。A「「マウス」キ以テセル 試驗: 體重 $15 \mathrm{~g}$ ハ「マウス」チ用ヒテ第 1 群八觀察用トシ。他ノ1群ハ病材用トス.

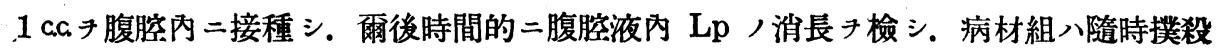
シテ累代通過, 成否キ检シタルニ. (1) No. 992 B株：「マウス」腹腔液內二 48 時間生 活 シ累代通過八成立セズ。(2) No. 997 B 株：腹腔液內二24 時間生活 シ. 累代通過八 成立セズ。（B）海猽キ以テセル試驗：體重 $150 \mathrm{~g}$ ，海猽キ選ビ前處置キ施サズ. $5 \mathrm{ca}$ 于腹腔內二接種シ。爾後腹腔液內二於ケル Lp 消長立海猽, 發病狀態チ觀察シタ ルニ. (1) No. 992 B 株八腹腔液內 $=48$ 時間生活 シ輕微ノ黃㾝惹起シタルノ $i 二$ テ健康狀態テ維持シタリ。（2）No. 997 B株八腹膑液內二 24 時間生活シ. 海猽二對シ テ發病狀態チ营起七ズ。以上ノ如ク.No. 992B 及 No.997B 兩株八. 其毒性二於 テ培養第 3 代二至レバ既二毒力ノ減弱著明ニシテ出發株ト等シキニ至ルチ認メタリ。 (II)培養世代ョ累加セルモノノ血清學的性狀：No: 992 B 及 No. 997 B兩株ノ培養第 
3 代丹弱毒株「七日熱」「ワィル」以上 2 種ノ冕疫血清二就テ其性狀キ檢シタリ。(A) 弱毒株「七日熱」血清二對シ No. 992 B株一一實驗後 2 時間ニシテ 320 倍. 4 時間ニシ テ 2560 倍 6 時間 5120 倍二陽性(第 66 表)．同血清二對シ No. $997 \mathrm{~B}$ 株八賽驗後 2 時

\begin{tabular}{|c|c|c|c|c|c|c|c|c|c|c|c|c|c|c|c|}
\hline \multirow{3}{*}{ 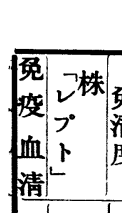 } & & & & 第 & & 66 & & & & & & & & & \\
\hline & & 稀釋可 檢 & 混入株 & 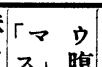 & 符 & \multicolumn{10}{|c|}{ 腹腔液檢查時日及成績 } \\
\hline & 清稀 & 清量混入株量 & \begin{tabular}{|}
$\exists$ 清血 \\
度
\end{tabular} & 曌注入 & 离 & $\begin{array}{l}\mathrm{m} \\
30\end{array}$ & $\begin{array}{l}\mathrm{h} \\
2\end{array}$ & $\ddot{4}$ & 6 & $\ddot{12}$ & $\ddot{24}$ & $\ddot{48}$ & $\begin{array}{l}\mathbf{t} \\
\mathbf{3}\end{array}$ & $\ddot{4}$ & $\ddot{5}$ \\
\hline \multirow{14}{*}{ 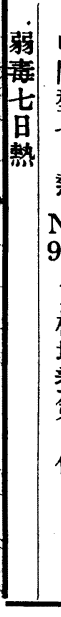 } & 10 & $|10 a c a+1 . c a|$ & 20 & $0.5 \rightarrow$ & 潢頭 & + & - & - & - & - & - & - & - & & \\
\hline & 20 & $n+n$ & 40 & $\because \quad \rightarrow$ & , 體 & + & - & - & - & - & - & - & - & & \\
\hline & 40 & $"+$. & 80 & $" \rightarrow$ & , 笪 & + & - & - & - & - & - & - & - & & \\
\hline & 80 & $"+$ & 460 & $\Rightarrow \rightarrow$ & 毒頭 & + & - & - & - & - & - & - & - & & \\
\hline & 160 & $"+\ldots$ & 320 & $" \rightarrow$ & , 體 & + & - & - & - & - & - & - & - & & \\
\hline & 320 & $"+$. & 640 & $" \rightarrow$ & , 睯 & + & + & - & - & - & - & - & - & & \\
\hline & 640 & $"+n$ & 1280 & $" \rightarrow$ & 赤頭 & + & + & - & - & - & - & - & - & & \\
\hline & 1280 & $"+n$ & 2560 & $\Rightarrow \rightarrow$ & , 體 & + & + & - & - & - & - & - & - & & \\
\hline & 2560 & $"+"$ & 5120 & $" \Rightarrow$ & , 雉 & + & + & + & - & - & - & - & - & & \\
\hline & 5120 & $" \quad+\quad$. & 10240 & $\Rightarrow \rightarrow$ & 紫頭 & + & + & + & + & + & + & - & - & & \\
\hline & 10240 & $"+n$ & 20480 & $\because \rightarrow$ & , 體 & + & + & + & + & + & + & - & - & & \\
\hline & 20480 & $"+$ & 40960 & 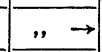 & , 睯 & + & + & + & + & + & + & - & - & & \\
\hline & 對照 & 培 & 株 & $0.25 \rightarrow$ & 黄手 & m & 曲 & H & Ht & H & + & - & - & & \\
\hline & 賽驗 & & & , $\rightarrow$ & , 足 & m & 亜 & $H$ & $t+$ & $t+$ & \pm & - & - & & \\
\hline & & & & 第 & & 67 & & & & & & & & & \\
\hline \multirow{2}{*}{ 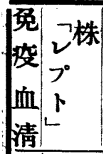 } & 疫血 & 稀釋可 檢 & 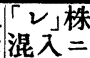 & $\left|\begin{array}{ll}\nabla & 9 \\
7\end{array}\right|$ & 对符 & & & 腔 & 液标 & 查 & 時 & 及 & 成 & & \\
\hline & 清稀釋 & 清衁混入糧洙 & \begin{tabular}{|l}
$\exists$ 清稀釋 \\
竞
\end{tabular} & 腔注入 & 齐 & $\begin{array}{l}\mathrm{m} \\
30\end{array}$ & $\begin{array}{l}\mathrm{h} \\
2\end{array}$ & $\ddot{4}$ & 6 & $\ddot{12}$ & $\ddot{24}$ & $\ddot{48}$ & $\begin{array}{l}\mathrm{t} \\
\mathbf{3}\end{array}$ & $\ddot{4}$ & $\ddot{5}$ \\
\hline \multirow{14}{*}{ 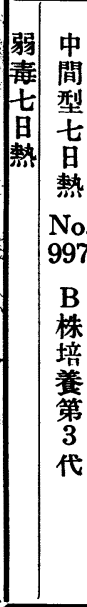 } & 10 & $1 . c a+1 . c a$ & 20 & $0.5 \rightarrow$ & 黄頭 & + & - & - & - & - & - & - & & & \\
\hline & 20 & 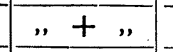 & 40 & " $\rightarrow$ & , 體 & + & - & - & - & - & - & - & & & \\
\hline & 40 & $" \pm$ & 80 & $" \rightarrow$ & , 睯 & + & - & - & - & - & - & - & & & \\
\hline & 80 & $"+n$ & 160 & $" \rightarrow$ & 青頭 & + & - & - & - & - & - & - & & & \\
\hline & 160 & $"+n$ & 320 & $" \rightarrow$ & , 體 & + & - & - & - & - & - & - & & & \\
\hline & 320 & $"+n$ & 640 &..$\rightarrow$ & , 繁 & + & - & - & - & - & - & - & & & \\
\hline & 640 & $"+n$ & 1280 & $\| \rightarrow$ & 赤頭 & + & + & - & - & - & - & - & & & \\
\hline & 1280 & $"+$ & 2560 & $\because \rightarrow$ & , 體 & + & + & - & - & - & - & - & & & \\
\hline & 2560 & $"+n$ & 5120 & $" \rightarrow$ & , 掣 & + & + & - & - & - & - & - & & & \\
\hline & 5120 & $"+$. & 10240 & $\because \rightarrow$ & 紫頭 & + & + & + & + & + & + & - & & & \\
\hline & 10240 & $"+\ldots$ & 20480 & $" \rightarrow$ & , 體 & + & + & + & + & + & + & - & & & \\
\hline & 20480 & $"+$, & 40960 & 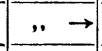 & ,翠 & + & + & + & + & + & + & - & & & \\
\hline & 對照 & 培 & 株 & $\begin{array}{c}0.25 \\
\mathrm{ac}\end{array} \rightarrow$ & & & & & & & & & & & \\
\hline & 實験 & & & $n \rightarrow$ & , 足 & & & & & & & & & & \\
\hline
\end{tabular}




\begin{tabular}{|c|c|c|c|c|c|c|c|c|c|c|c|c|c|c|c|c|}
\hline & & & & & 第 & 6 & & & & & & & & & & \\
\hline \multirow{2}{*}{$\begin{array}{l}\text { 免 } \\
\text { 度 } \\
\text { 血 } \\
\text { 清| }\end{array}$} & \multirow{2}{*}{$\mid \begin{array}{c}7 \\
2 \text { 株 } \\
7^{\circ} \\
1 \\
2\end{array}$} & \multirow{2}{*}{\begin{tabular}{|l} 
免疫血 \\
清稀釋 \\
度
\end{tabular}} & \multirow{2}{*}{\multicolumn{2}{|c|}{ 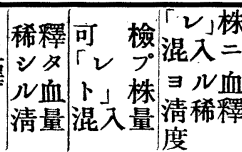 }} & \multirow{2}{*}{$\left|\begin{array}{ll}\ulcorner & \text { ウ } \\
\text { ス」复 } \\
\text { 腔注入 }\end{array}\right|$} & \multirow{2}{*}{ 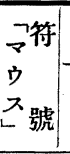 } & \multicolumn{10}{|c|}{ 腹腔液檢查時日 及成 績 } \\
\hline & & & & & & & $\begin{array}{l}\mathrm{m} \\
30\end{array}$ & $\begin{array}{l}\mathrm{h} \\
2\end{array}$ & $\ddot{4}$ & $\ddot{6}$ & $\ddot{12}$ & $\ddot{24}$ & $\ddot{48}$ & $\begin{array}{l}\mathbf{t} \\
\mathbf{3}\end{array}$ & $\ddot{4}$ & $\ddot{5}$ \\
\hline \multirow{14}{*}{ У } & \multirow{7}{*}{$\begin{array}{c}\text { 中 } \\
\text { 間 } \\
\text { 型 } \\
\text { 㫐 } \\
\text { 熱 } \\
\text { No. } \\
992\end{array}$} & 10 & $1 . c . c+1 . c . c$ & 20 & $0.5 \rightarrow$ & 橫頭 & 册 & 册 & $H$ & $+t$ & $+t$ & + & - & - & & \\
\hline & & 20 & $n+n$ & .40 & $" \rightarrow \rightarrow$ & , 體 & 册 & 册 & t+ & $+t$ & $H$ & + & - & - & & \\
\hline & & 40 & 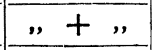 & 80 & $" \rightarrow$ & , 臂 & 册 & 册 & $+t$ & $+t$ & t+ & + & - & - & & \\
\hline & & 80 & $"+$, & 160 & $\rightarrow$ & 毒頭 & 册 & 册 & t+ & $+t$ & $+t$ & + & - & - & & \\
\hline & & 160 & $"+$, & 320 & $" \rightarrow$ & , 體 & 册 & 曲 & tt & t+ & + & + & - & 一 & & \\
\hline & & 320 & + & 640 & $", \rightarrow$ & , 臂 & • 曲 & 册 & $+t$ & $+t$ & $t+$ & + & - & - & & \\
\hline & & 640 & $"+$, & 1280 &,$\quad \rightarrow$ & 赤頭 & 册 & 冊t & $+t$ & $+t$ & $+t$ & + & - & - & & \\
\hline & \multirow{7}{*}{$\begin{array}{c}\mathrm{B} \\
\text { 株 } \\
\text { 培 } \\
\text { 㝨 } \\
\text { 第 } \\
\mathbf{3} \\
\text { 代 }\end{array}$} & 1280 & $"+$, & 2560 & $", \rightarrow$ & , 體 & 册 & 册 & $t+$ & $t+$ & $+t$ & + & - & - & & \\
\hline & & 2560 & $"+$ & 5120 & $", \rightarrow$ & , , 臂 & 册 & 册 & $t+$ & $t+$ & $t+$ & + & - & - & & \\
\hline & & 5120 & $"+$, & 10240 &.$\quad \rightarrow$ & 紫頭 & 冊 & 册 & $H$ & $+t$ & $+t$ & + & - & - & & \\
\hline & & 10240 & $"+$, & 20480 &,$\quad \rightarrow$ & , 體 & 册 & 册 & $t+$ & $+t$ & $t+$ & + & - & - & & \\
\hline & & 20480 & $"+$, & 40960 &,$\quad \rightarrow$ & ,, 䏿 & 曲 & 册 & tt & $+t$ & $+t$ & + & - & - & & \\
\hline & & 對照 & 培 & 株 & $\begin{array}{r}0.25 \\
\mathrm{c.c}\end{array} \rightarrow$ & 黃手 & 册 & m & t+ & H & t+ & + & - & - & & \\
\hline & & & & & $\because \quad \rightarrow$ & , 足 & 曲 & 曲 & tt & tt & $+t$ & + & - & - & & \\
\hline
\end{tabular}

間ニシテ 640 倍. 4 時間ニシテ 5120 倍二陽性(第 67 表)。(B).「ワィル」冕度血清二對 シ No. 992B株一陰性(第 68 表). No. 997 B株モ亦陰性(實驗表省略)。以上ノ如ク 中間型性狀チ示入「七日熱」，世代累加第 3 代二至レバ既二其毒性二於テモ亦黑疫血清 學的性狀ニ於テモ容易二出發株二復歸シタリ。

如上ノ成績ヨリ中間型性狀チ示入理由八「七日熱」が「ワイル」性狀チ帶ブルニ至りタ ル結果ナリト思惟ス。

\section{第三節 强毒株「七日熱」ヨ出發弱毒株「七日熱」ニ復歸}

$$
\text { セシムル實驗 }
$$

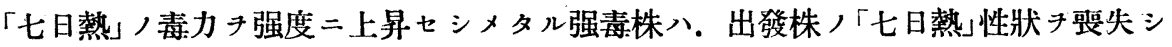
テ「ワイル」ト其毒性二於テモ亦蛮疫血清學的性狀ニ於テモ區別シ難キ性狀キ示ス八既 二詳論セシ所ナリ．本篩ニ於テハ上記强毒株チシテ培養世代ォ累加シ以テ其毒力ォ人 工的二低下七シメ再ビ出發株二復歸入ルヤ否ヤチ检討シタリ.本培養實驗ハ第 30 代マ デハ福島氏培地キ以テ 4-5 日目二移植キ累ネタリ.然ルニ本培地八 $\mathrm{Lp}$ ，發有二最モ 好適シ Lp /毒力八容易二低下シ難キチ知リタルキ以テ。爾後ハ福島氏培地，蛋白質 尹 $1 / 4$ 二減量セシメタルモノ或ハ之二加フル二海猽血液ノ添加チ微量ナラシメタル

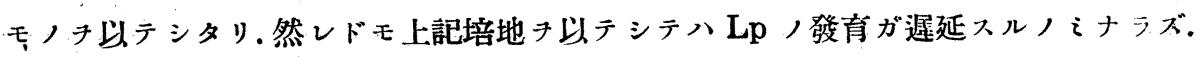


第 69 表

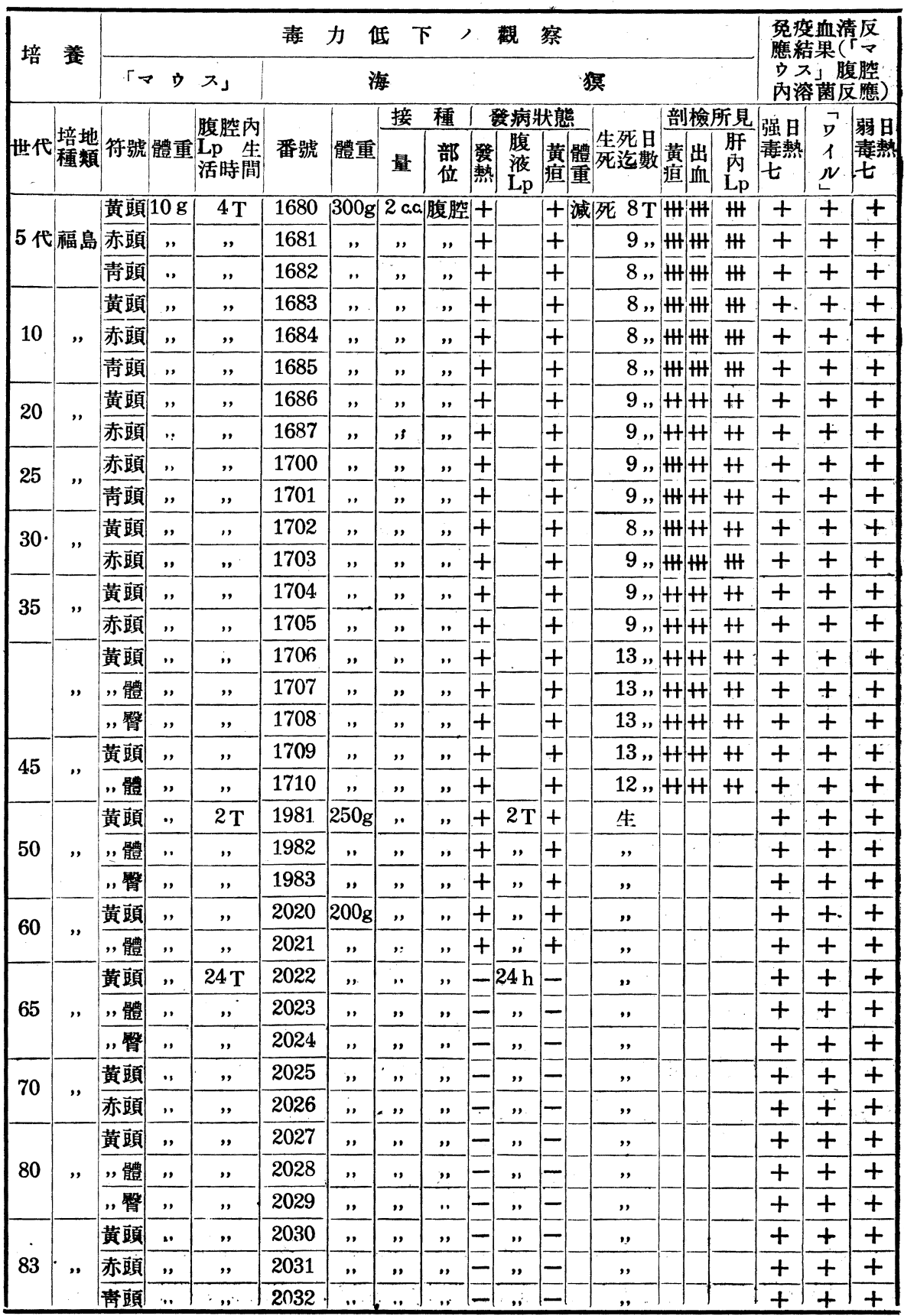

シタル Stämme，保存スラ困難キ感ジタルニョリ。時タ適宜二福島氏原法培地キ以 
世代キ累加テ培養シ 2-3 週每ニ世代チ累加シッ、實驗キ續行セリ。

上記培養世代，累加株二反シ。强毒株丹海猽ヨリ分離シ得タル第 1 代株中（福島氏 培地二約 $1 \mathrm{~cm}$ ノ「流動バラフィン」キ重層セシメタルモノ)滿 2 ケ年 8 ケ月間 $\mathrm{Lp}$ ノ生 存シタルモノキ選ビ。之キ福島氏培地二培養增殖シタル第 2 代株二就テ.其毒性竝二免 疫血清學性狀チモ檢シタリ。以上ノ培養株二就テハ何レモ「マウス」腹鳃液內二於ケル 生活時間及ビ海猽ノ發病狀態ニョリテ毒カョ檢シ更ニ「マヴ入」腹腔液內溶菌反應き檢 證シタリ。本實驗成績入(第 69 表) ニ一括シテ示入ガ如ク．福島氏培地チ以テシタル 第 30 代ノ毒性ハ「ウス」腹腔液內 $=4$ 日間. 海猽ニ對シテハ 8-9 日ニシテ. 定型的 应狀ノ下二罹患整死セシメ。此培地ノ蛋白質及海猽血液添加ノ微量トナシタル培地キ

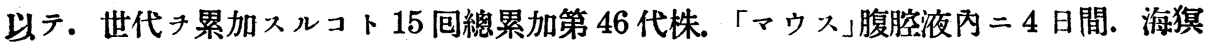
キ 12-13 日ニシテ定型的症狀 下二罹患整死七シメ.稍了ソノ致死日數き延長セシメ タルォ見タリ。上記累代培養株ハ其免疫血清學的性狀丹檢スルニ何レモ强毒株「七日 熱及「ワィル」免疫血清二陽性キ示ス二反シ. 弱毒株「七日熱」ハ陰性キ示入。郎于依 然トシテ「ワィル」性狀キ示シテ「七日熱性狀キ示サズ。培養第 50-60 代株八其毒性 「マウス」腹腔液內 $=2$ 日間. 海犋二對シテハ䡛微ノ發熱黃疸き惹起スルノiニテ該海 猽八健康二復シタリ。第 65-83 代株ハ「マウス」腹腟液內二 24 時間生存シ海猽二對シ テ 六病的症狀テ惹起七ズ。上記第 50-83 代株ノ免疫血清學的性狀八强毒株「七日熱」及 「ワィル」兩株ノ血清二對シテ陽性キ示シ．弱毒株「七日熱」對シテハ陰性ォ示ス。他 方本强毒株「七日熱」テ分離シタル第 1 代ノ滿 2 ケ年 8 ケ月間生存シタルモノノ毒性竝 二免度血清學的性狀テ檢タシルニ. 之其毒性二於テハ「マウス」腹愘液內 $=24$ 時間ノ 々生活 シ海猽二對シテハ發病力ナク．冕疫學的性狀八强毒性「七日熱」「ワィル」兩種 ノ血清ニ對シテ陽性き示シ。弱毒株「七日熱」ンハ陰性チ示シタリ。以上成績キ通覽ス $ル ニ$ 本强毒株「七日熱了八培養世代累加スルコト第 65 代. 他方二八福島氏培地二テ 2 ケ年 8 ケ月間生存シタル培養株何レモ其毒性二於テハ。出發株卜區別シ難キモノトナ リタルモ其免度學的性狀八. 培養第 83 代二至ルモ依然トシテ「ワィル」樣性狀チ示シ。 容易二出發元株ノ弱毒株「七日熱性狀二復歸セボルチ知りタリ。

\section{第四節 本章ノ小括}

(1)「マウス」腹腔液內二於テ 3 日間生存シ。海猽ニ對シテハ轅微ノ罹患症狀キ惹起

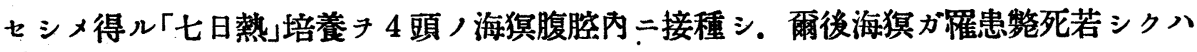
自然治虑キ營々タル全經過中二於テ. 各海猽ヨり接種後第 3 日二分離シ得タル 4 株入 
悉ク「七日熱性狀き示シ。第 5 日二分離シ得タル 2 株ハ「七日熱ト「ワイル」トノ中間

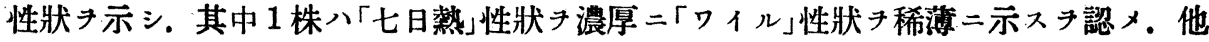
ノ1株ハ「七日熱」性狀ヨリモ「ワイル」性狀キ濃厚二示スタ認メ、第 1-12 日二於テ 分離シ得タル 4 株站二 3 株ノ肝藏內 $\operatorname{Lp}$ 八何レモ「ワイル」ト區別シ難キ性狀キ示スタ 認メタリ。郎チ「七日熱」八動物體內二於テ毒力ノ强度キ上昇スルト共二出發株本性， 「熱性狀ヨリ漸次「マイル」樣性狀二推移シテ。恰力モ「七日熱」ト「ワィル」トノ中 間性狀丹示シ遂二本性丹喪失シテ「ワィル」ト全ク區別シ難キニ至ル。

(2)「七日熱」トワイル」トノ中間性狀チ示ス所謂中間型「七日熱」ハ（A）毒力八强 度ハ「マウス」腹腔液內二於テ 4 日間生活シ。「マウス」累代通過八接種後 24 時間以內 ノ $i 二$ 於テ可能ナルモ爾後,時間二於テハ成立七ズ. 體重 $150 \mathrm{~g}$ ，海猽二對シテ腹胫 內 $=5$ c.c. 午接種七ル 間型「七日熱」キ抗原トシテ製作シタル免疫血清入抗原卜同一性狀キ示スキ認メタリ。 （C）中間型「七日熱」八培養世代チ累ネテ第 3 代二至レバ既二其毒性二於テモ亦免废血 清學的性狀二於テモ。出發シタル弱毒株「七日熱性狀二容易二復歸ス。

（3）「七日熱」强毒化株き福島氏培地二培養世代.累加スルコト 35 代. コノ蛋白質 丹 $1 / 4$ 二減量シタルモノチ以テ培養スルコト 25 代以上合計 65 代ノ培養累加ニョリテ 其毒性二於テハ出發株ノ弱毒株「七日熱」ト等シキニ復歸シタリ。然ル二叒疫血清學的 性狀ハ依然トシテ「ワイル」ト區別シ難キ性狀き示ス。泫二於テ海猽ノ血液添加量き更 二減量シタル本培地 然トシテ「ワイル」樣性狀チ示スキ認メタリ。他方 2 ケ年 8 ケ月，長日月間生活シ得タ

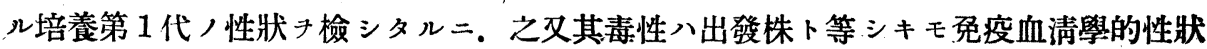
ハ「ワィルト區別シ難キチ認メタリ．郎チ强毒株ハ其毒性ハ出發株ト等シキ二復歸入 ルモ，免度血清學的性狀八容易二復歸セズ。

\section{第七章 本編ノ考察及總括}

Lp 八種屬異同檢討ノ第メ.Pfeiffer 氏反應. 大庭氏反應 Uhlenhuth 氏反應. Rieckenberg 氏反應等キ對比精查シタルニ. 何レモ滿足スルニ足ル。結果キ得ザルォ 遺憾トシ「マウス」腹腔キ藉リテ $\mathrm{Lp}$ ノ溶菌現象キ檢スル 1 種ノ免疫血清反應タ考案シ 圭トシテ本反應ニョリテ賽驗シタリ。種屬異同二關シテハ. 毒力ォ强度二上昇セシメ タル各種 $\mathrm{Lp}$ 二就テ檢討スヘチ主眼トシ更ニ Lp 八毒力八强弱ニョリテ性狀二相異タ

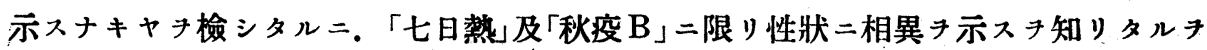


以テ特二「七日熱」性狀變化二關ス儿研究二於テ.夫ンノ出發弱毒株ヨリ强毒變性株 二至几其間二於ケル性狀變化，推移動向過程キ明ラカニスルト共二. 變性株が再ビ出. 發株二復歸スルヤ否ヤチ檢シタリ。ソノ實驗成績キ總括スルニ.

（I）充疫血淸反應二就テ：（1）Pfeiffer 氏反應ハ Lp ノ種屬中毒力ノ動搖著シキ

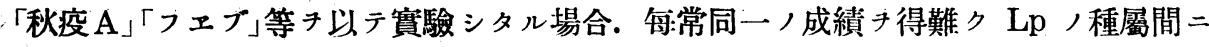

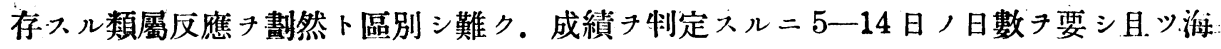
猽八實驗中他, 疾患等ニョリ獘死スル場合多ク實驗操作ノ煩雜き遗澸卜ス。(2)大庭 氏反應八實驗成績ノ陽性. 陰性. フ劃然卜區別シ難キ場合アルノぇナラズ. 成績制定 こモ3-4 日チ要久。（3）Uhlenhuth 氏文應八操作必ラズシモ容易ナラズ.且ツ成績

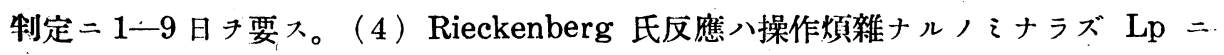
於テ八帶荷現象ノ判定キ誤認シ易シ。（5）「マウ入」腹腷內溶菌父應八免疫體ノ有無 定性的二其强弱 定量的二. 可檢 $\mathrm{Lp}$ /毒力强弱丹モ併七知リ. 實驗成績像八劃然卜 シテ疑標ナク.成績判定ハ 2-4 時間ニシテ足り。操作簡易ニシテ經沙的ナル特徵チ有

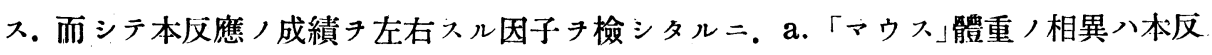
應ノ成績二差異丹示サズ。 b. 可檢 $\mathrm{Lp}$ 八培養ハ新鮮ナルモノ程溶菌現象キ起シ難ク 陳舊ナルモノ程之チ起シ易シ。c. 可檢 $\mathrm{Lp}$ 人毒力强キモノ八溶菌サし難ク.弱毒ナル モノ八之二反久。d. 冕疫價, 强キ血清程溶菌慒高シ。e. 毒力强キ Lp キ抗原トシテ

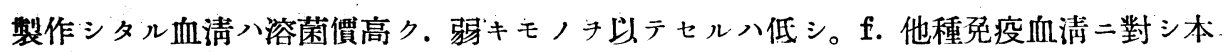
反應八成立七ズ。（6）「マウ大」腹膑內溶菌反應卜。他，免疫血清父應卜）成績子比較

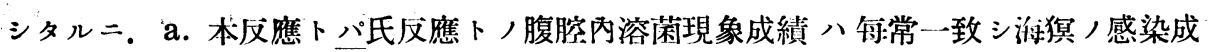
否モ亦一致入。b. 本反應卜大庭氏及U氏反應卜ノ成績丹比較 血清稀释度 40960 倍ノ溶菌價 示ス二對シ。大庭氏反應ハ 2560 倍. U氏反應ハ 5120 倍ナ示シ. 前者二免疫價ノ現ハレ方遙カ二顯著ナリ。c.「マウ入」腹腔內溶菌反應成績 八. 40960 倍キ示ス二反シ， R氏反應帶荷現象ハ 80-160倍キ示ス二過ギズ。

（II）種屬異同二關シテハ：Lp，毒力ォ强度二上昇安定均等ナラシメタル狀態二於 テハ. (1)「ワィル」「「黃熱」「七日熱」「秋疫 $\mathrm{B}_{2\lrcorner}$ 。「秋疫 $\mathrm{B}_{1\lrcorner} . \mathrm{Lp}$ 八何レモ相互一 致ノ性狀キ示シ。(2)「フェブ」ハ上記 Lpト一定度/類屬反應タ呈スルモ. 其性狀キ異

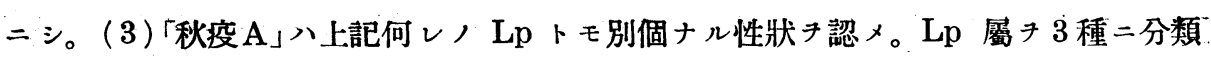
シ得タリ。

（III) $\mathrm{Lp}$ 入毒力八强弱ニヨ.リテ免疫血清學的性狀二相異チ示スヤ否ヤチ檢シタルニ

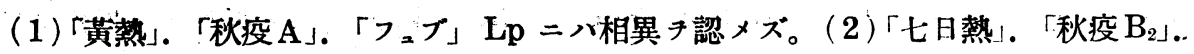


「秋度 $\mathrm{B}_{1\lrcorner \mathrm{Lp}}$ ハ相異キ來スコトキ認メタリ。

（IV）「七日熱」性狀戀化二關シテハ：（1）動物體內二於テ毒力ォ强度二上暴セシム ルト共二「出發株」ノ「七日熱」性狀ヨリ㖾次「ワイル」樣性狀二移行シテ。恰カモ「七日

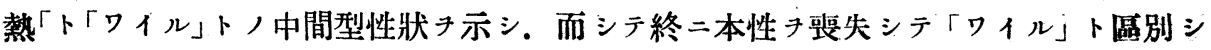

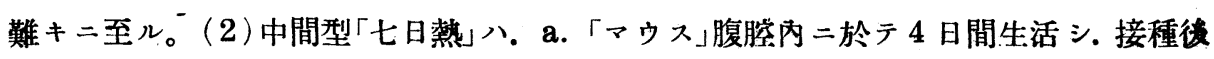
24 時間以內二於テ, $i 「 マ ウ \lambda 」$ 累代通過八成立シ. 爾後, 時間二於テハ腹腔夜內二 Lp 7證明スル時ト雖モ成立セズ.小ナル海猽二對シテハ 5 c.c. ノ大量接種ニョリテ.914 日ニシテ罹患敝死七シム。b. 中間型「七日熱」⿻抗原トシタル怎疫血清八. 抗原二 一致入ル性狀ォ示シテ. 抗體產成生能二矛盾ナシ。 c. 中閐型「七日熱山培養世代ォ重

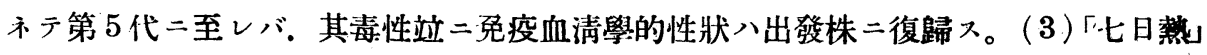
ノ强毒株ハ. 培養世代ノ累加第 65 代二於テ其毒性ハ本來ノ弱毒株「七日熱」等シキニ 復歸シタルE. 冕疫血清學的性狀ハ依然トシテ「ワイル」樣性狀チ示入弦二於テ Lp， 發有二不適當培地于求メテ更二 18 代郎チ總計 83 代ノ世代累加チナスモ.前同樣「ワイ ル」性狀キ呈シテ「七日熱」復歸セズ. 又福島氏培地内二於テ滿 2 ケ年 8 ケ月間生存シ タル培養第 1 代株丹檢シタル二。文又毒性二於テハ出發株ト等シキモ。其性状八依然 トシテ「ワィル」性狀キ示シタリ．郎チ人丁的二强毒株トナシタルモノ八. 容易二出發 株二復歸セズ。

以上子通覽入ルニ，余ノ考案ニナル「マウス」腹腔內溶菌反鷹ハ L Spirochaeta 若シクハ Chleravibrio 等溶菌現象 き以テ示標トスル免疫血清反應二應 用スルチ得。

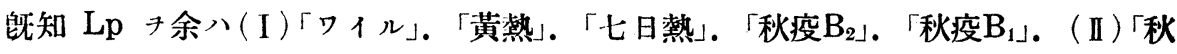
疫 $\mathrm{A}\lrcorner$.（四）「フェブ」ノ 3 種屬二分類シ得タリ。之キ先人學者ノ（I）「ワィル」「黃熱 （II）「七日熱」及「秋疫 $\mathrm{B}\lrcorner$ 。（III）「秋疫 $\mathrm{A}\lrcorner$ 。（IV）「フェブ」(「ワィル」二近緣性キ示スルキ 以テ「ワイル」屬セシメントシタル)ト二分類セルモノトキ對比スル二.余ノ分類二於 テハ「七日熱及「秋疫B」キ「ワィル」ニ屬セシメ・「フェブ」ハ「ワィル」二近緣性キ有スト 雖モ他種 Lp ト全ク別個ノ性狀丹示ス 1 種屬タルタ認メタル點二於テ相異ス。 之レ里 竟先人ハ Lp ガ自然的二個有スル性狀二就テ論ジテ Lp 相互間ノ毒力ノ相異き顧慮七 ズ. 反之余八各種 Lp ノ毒力キ强度二上昇セシメテ之ォ一定標準ニ持チ來シ・以テ免 疫體形成ノ均等キ圖リタル狀態二於テ檢討シタル結果トス。

依之余八「七日熱」及「秋疫 $\mathrm{B}_{\lrcorner}$二關スル新知見キ提唱スルト共ニ「「フェブ」關スル 從來ノ說き是正セント欲スルモノナリ。「七日熱が性狀タ變化スルャ否ャニ關シテハ 
（1）出發株.（2)變性株及兩者ノ中間株性狀ヲ檢討シテ. 出發株ョリ變性株ニ至ル其

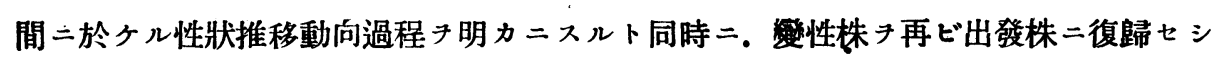
メザル限リ變性問題キ論結 シ難シト信ジ。同一株二就テ一系統ノ下二賽驗シタル結果 强毒株ガ出發株二復歸スルヤ否ヤハ㗔カ二推論タ許サズト雖モ。「七日熱ハ毒力キ强 度二上昇セシメタル場合「ワィル」ト區別シ難キ性狀キ示ス二至り．而カモ一旦「ワィ ル」性狀丹呈スルニ至レバ容易二出發株二復歸セザルモ,ト言七得可シ。

\section{後編 能倬免疫學的研究}

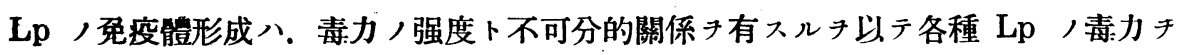
「ワィル」夫レトホ、均等ナラシメ.上テ兑疫體形成ォ均等ナラシメタル狀態二於テ 種屬異同キ檢討セリ。本實驗二供セル「ワクチン」ハ何レモ同一ノ方法キ以テ製シ. 抗 體形成力キ測定シテ其抗原力ノ略 く均等ナルモノキ選ビタリ。可檢 $\mathrm{Lp}$ ハ何レモ培養 2 c.c. キ體重 300-350g ，海猽腹腔內二接種スルニ.5一-7 日ニシテ罹患鷩死七シムル 强毒株キ以ォシ。，且ツ各種 Lp，培養モ亦同一條件ノ下二於テ實驗二供シタリ。從來 Lp /能働免废學的研究八. 專ラ海猽キ以テ實驗七ラレタルガ. 余ハ「マウス」二能働

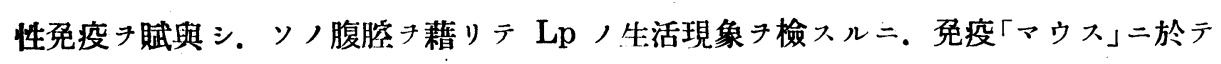
八 $\mathrm{Lp}$ 八速カ二死隇融解シ.ソノ時間的關係八對照賽驗ノソレ二比シ. 格段ノ相異チ 認メタルキ以テ. 本方法ニョルト同時二海猽二對シテモ能働性免疫キ賦與シ. 兩者三 ヨリテ各種 $\mathrm{Lp} /$ 異同キ比較研究シタリ。

\section{第一章 試供「ワクチン」二就テ}

$$
\text { 第一節「ワクチン」ノ製作 }
$$

「マウス」キ以テ毒力チ强度二上昇セシメ. 更二5-26代，海猽累代通過ニョリテ. 其毒力丹强固安定ナラシメタル。强毒株キ以テ「ワクチン」チ製シタリ。本强毒株ハ 2

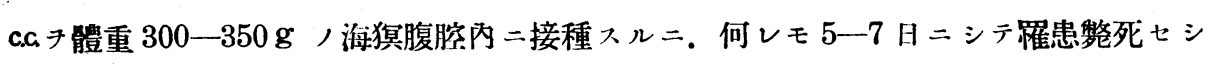
ム. ソノ培養八何レモ福島氏培地二 7 日間培養シ $L p$ ／每視野 20 個內外發有七几モ ノチ選ビ。隇菌「ガーゼ」キ以テ滤過シ. $56^{\circ} \mathrm{C}=$ テ 30 分間加熱隇藏シ. 石炭酸キ加へ ズ水室二貯藏入。

$$
\text { 第二節「ワクチン」ノ種類. }
$$

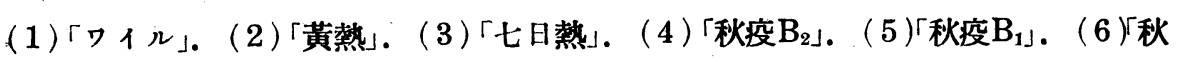


疫 $\mathrm{A}\lrcorner .(7) 「 フ ェ フ ゙ 」$ 以上 7 種類トス。

\section{第三節 各種「ワクチン」ノ抗體產生力測定}

各種「ワクチン」ノ抗體產生力八. 後二詳述スル方法キ以テ檢シタルニ以下/溶菌值 キ示ス。賽驗表 (70 表「ワィル」テ代表トシ他ハ省略ス)。

\begin{tabular}{|c|c|c|c|c|c|c|c|c|c|c|c|c|c|c|c|c|c|c|c|c|c|c|c|c|}
\hline & & & & & & & & 第 & & 70 & & & & & & & & & & & & & & \\
\hline$\nabla$ & 「マウ & נ & & & סעי & & $\eta$ & F & ע. & & & & $\begin{array}{l}\text { 生且 } \\
\text { 接程 }\end{array}$ & & & 复望 & 液 & 檢う & 查日 & 時日 & 日及 & 珹 & & \\
\hline$F$ & & & & & $r_{\nabla}$ & म & ス」腹 & 复腔 & 內 注 & 射 & & & & & & & & & & & & & & \\
\hline 種 & 符號 & 體重 & 稀釋 & 第 1 & 间 & & 管 2 & 回 & & 3 & & 綿 & 注 & 量 & $\begin{array}{l}\mathbf{m} \\
30\end{array}$ & $\begin{array}{l}\mathbf{h} \\
2\end{array}$ & $\ddot{4}$ & $\ddot{\mathbf{6}}$ & & $\ddot{2} 4$ & $\ddot{48}$ & $\begin{array}{l}\mathbf{t} \\
\mathbf{3}\end{array}$ & $\ddot{4}$ & " \\
\hline & & & & 月日 & 量 & 月日 & 間晍 & 量 & 月 & 間隔 & 量 & $\begin{array}{l}\text { ク 射 } \\
\text { 千量 }\end{array}$ & 隔 & & & & & & & & & & & \\
\hline & 潢頭 & $10 \mathrm{~g}$ & & & 0.15 & 6 & & 0.35 & $10 /$ & & $0: 5$ & & & 0.3 & $t$ & & - & -1 & - & - & -1 & -1 & & - \\
\hline$\nabla$ & , 體 & ", & 谙 & $/ x$ & c.a & X & $4 \mathrm{t}$ & ca. & 8 & $4 \mathrm{t}$ & c.a & 1 c.a. & $4 \mathrm{t}$ & c.a & + & 二 & 二 & 二 & 二 & - & 二 & 二 & & \\
\hline 1 & , 腎 & ", & & & & & & & & & & & & & + & + & + & 二 & 二 & 二 & 二 & 二 & $=$ & $\overline{-}$ \\
\hline & 赤頭 & ", & 10 & $"$ & $"$ & $"$ & $"$ & $"$ & $"$ & $"$ & $"$ & " & $"$ & " & $t$ & + & + & 二 & 二 & 二 & - & -1 & 二 & $=$ \\
\hline & , 體 & , & & & & & & & & & & & & & + & + & $\bar{t}$ & - & 二 & 二 & - & - & - & - \\
\hline & , 䁂 & ", & 20 & " & ", & "' & $"$ & ", & ." & " & $"$ & " & " & "' & $\bar{t}$ & + & $\bar{t}$ & 二 & - & 二 & 二 & $=$ & 二 & 二 \\
\hline & 青頭 & ", & 40 & & & & & & & & & & & & $H$ & $H$ & + & + & + & 二 & 二 & 二 & 二 & Z \\
\hline & , 體 & ." & 40 & $"$ & $"$ & " & " & " & $"$ & $"$ & $"$ & " & $"$ & $"$ & $H$ & H & \pm & + & \pm & - & - & 二 & - & Z \\
\hline & ", 霄 & , & 0 & & & & & & & & & & & & HI & $\mathrm{HI}$ & $t+$ & +4 & + & - & - & - & 二 & - \\
\hline & 紫頭 & $"$ & ov & " & "' & $"$ & $"$ & $"$ & " & $"$ & $"$ & $"$ & $"$ & $"$ & $\mathrm{HH}$ & H & $t+$ & $H$ & + & - & - & 二 & - & - \\
\hline & 黃手 & ", & & & & & & & & & & & & & $\mathrm{HH}$ & HI & $\mathrm{HI}$ & $+t$ & $+t$ & + & - & - & - & - \\
\hline & 黄足 & ", & 100 & $"$ & "' & $"$ & $"$ & $"$ & $"$ & $"$ & " & "' & $"$ & $"$ & H & HI & \# & $H$ & $H$ & \pm & - & - & - & $\overline{-}$ \\
\hline & 赤手 & " & & & & & & & & & & & & & HI & \# & HI & $H$ & $H$ & \pm & + & 二 & - & - \\
\hline & 赤足 & ", & $3 z 0$ & "' & $"$ & "' & " & " & "' & $"$ & $"$ & $"$ & $"$ & $"$ & $\Pi$ & 4 & $\overrightarrow{H I}$ & $+H$ & $H$ & + & + & - & 二 & - \\
\hline & 靑手 & $"$ & & & & & & & & & & & & & 册 & in & 표 & HI & $H$ & $\mathrm{H}$ & \pm & \pm & - & - \\
\hline & 毒足 & ", & 640 & $"$ & $"$ & " & $"$ & $"$ & $"$ & $"$ & $"$ & $"$ & $"$ & " & III & & 世形 & III & & III & & \pm & & - \\
\hline & 紫手 & $"$ & & & & & & & & & & & & & III & Iifit & HII & 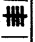 & 표 & \#I & $t$ & \pm & \pm & \\
\hline & 紫足 & , & & & & & $M$ & & & & & & & & 亜 & & 曲 & $\overline{\text { 册 }}$ & $\overline{\text { 册 }}$ & HA & $\bar{H}$ & + & \pm & \\
\hline
\end{tabular}

（1）「ワイル」一640倍.（2）「黃熱」一640倍．（3）「七日熱」一640倍.（4）「秋疫 $\mathrm{B}_{2 」}$ -640 倍. (5)「秋疫 $B_{1\lrcorner}-640$ 倍.（6）「秋疫 $\left.A\right\lrcorner-320$ 倍.（7）「フェブ」一320 倍。

\section{第二章「マウス」ニ就テノ賽驗}

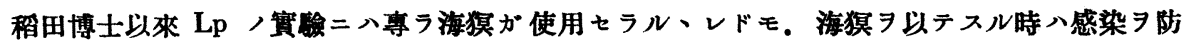

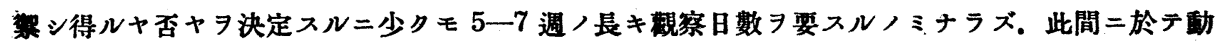

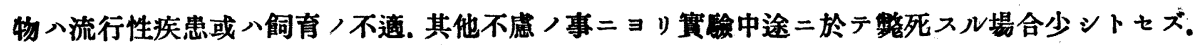

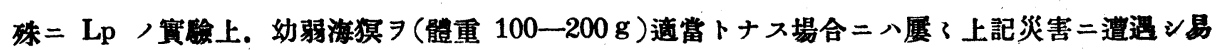

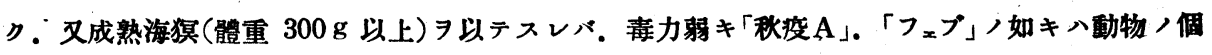


性ニヨリテ感染，有無乃至八曜患程度 $コ$ 異ニシ. 成績制定二困難 ヨ感ズル場合アリ. 其他毒力，

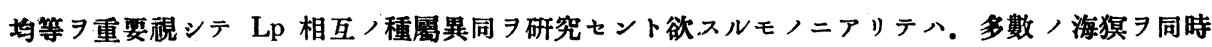

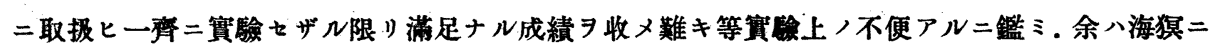
代フルニ强健ニシテ且ッ取报ヒ二便利ナル「マウス」ヨ以テシ.之二能動性免疫习賦與シ該「マウ

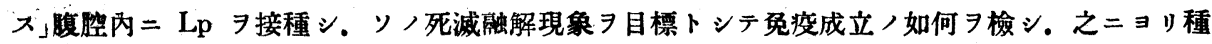

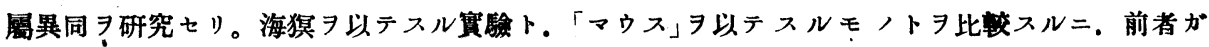
動物, 感染成否 $\exists$ 檢查スルニ對シ。後者八病原體, 死隇如何 $ᄏ$ 直接的二檢查スル相違 $ᄏ$ 有ス。

\section{第一節 免疫賦與ノ基本實驗}

\section{第一項 免疫践與二要スル「ワクチン」量站ニ「ワクチン」注射後免疫}

\section{現象ノ彊現スル日数ノ檢討}

能働性色疫キ賦與スルニハ「ワクチン」微量ヨリ浙次增量シ。一定間隔キ以テ反復 スルチ通例トス．然レドモ之二要スル「ワクチン」量站二使用方法二關シテハ「「ワクチ ン」ノ材料タル Lp，毒性泣二數量的相異ニョリ。他方二八動物ノ種類ニヨリテ異ナ ル所ナル可シ。「マウス」二能働性免疫キ賦與スルニ要スル「ワクチン」ノ使用量立二」ワ クチン」注射後第何日目二免疫性現象キ發現スルヤチ知ラント欲シ「「イルワクチン」 キ以テ以下ノ如ク賽驗キ試ミタリ。

I. 種々異ナル「ワクチン」量キ唯 1 回注射シタル場合：「ワクチン」注射量八從來海 猽キ以テ實驗セラレタル用量キ標準トシテ。「マウス」體重 $10 \mathrm{~g}$ 二對シ。第 1 群ニハ 0.001 c.a. 第 2 群二ハ 0.01c.c. 第 3 群二ハ 0.1 c.c. 第 4 群二ハ 0.3 c.c. ‡何レモ皮下二 注射シ。爾後各群共第 4-7-10-14 日二 Lp 培養子腹膑內二接種シ.ソノ後時間的

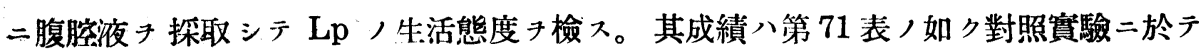
Lp ハ4 日間生活スルチ認ムルニ對シ.（1）「ワクチン」0.001c.c. 站 = 0.01c.a 注射群 八. 何レモ注射後第 4-7-10-14 日二於テハ對照ノソレト相違キ見ズ。(2)0.1c.c.注 射群ハ。注射後第 4-7 日二於テハ對照群ト相違チ見ズ。然ル二第10-14 日二於テハ 3 匹中 2 匹二於テ $\mathrm{Lp}$ 八對照 $コ モ 24$ 時間早ク死隇融解シ。第 14 日二於テハ 3 匹何 レ`モ 24 時間早ク死隇融解スルタ認メタリ。(3) 0.3c.c 洼射群八. 注射後第 4-7 日二 於テハ對照ト相違キ見ズ. 然ル二第 10 日二於テハ何レモ 24 時間第 14 日二至リテハ

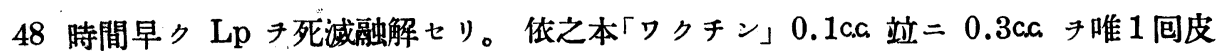
下二注射シタル各「マウス」群八. 注射後第 10-14 日ノ日數キ經レバ. 腹膑內二接種 七ル Lp 于對照二比シ 24-48 時間早ク死堿融解セシムルチ認メタリ。

II. 一定「ワクチン」量チ分割注射シタル場合：前賽驗ニョリ．體重 $10 \mathrm{~g}$.ノ「ウス」 
第 $71 \quad$ 表

\begin{tabular}{|c|c|c|c|c|c|c|c|c|c|c|c|c|c|c|c|c|}
\hline \multicolumn{2}{|c|}{ 「マウズ } & \multicolumn{2}{|c|}{$\begin{array}{l}\text { 『クチン」 } \\
\text { 注射 }\end{array}$} & \multicolumn{3}{|c|}{ 生活 Lp 接種 } & \multicolumn{10}{|c|}{ 腹腔液檢查時 日 及成績 } \\
\hline 組別 & 符號 & 量 & 部位 & $\mid \begin{array}{cc}\text { 口 } & \text { 注 } \\
1 & , \\
\text { 間隔 } \\
\text { 日數 }\end{array}$ & 量 & 部位 & $\begin{array}{l}\mathrm{m} \\
30\end{array}$ & $\begin{array}{l}\mathrm{h} \\
2\end{array}$ & $\ddot{4}$ & $\ddot{6}$ & $\ddot{12}$ & $\ddot{24}$ & $\ddot{4}$ & $\begin{array}{l}\mathbf{t} \\
3\end{array}$ & $\ddot{4}$ & $\ddot{5}$ \\
\hline \multirow{5}{*}{$\mathbf{A}$} & 黄頭 & \multirow{2}{*}{$0.001 \mathrm{c} a$} & \multirow{2}{*}{ 皮下 } & \multirow{2}{*}{$4 \mathrm{t}$} & \multirow{2}{*}{$0.3 \mathrm{ca}$} & \multirow{2}{*}{ 腹腔 } & 册 & Hitt & Hill & \#I & \# & HI & $t+$ & + & + & - \\
\hline & , 體 & & & & & & 册 & +m & 燕 & H & H & 世 & t+ & + & + & - \\
\hline & 赤頭 & \multirow[b]{2}{*}{$"$} & \multirow[b]{2}{*}{$"$} & \multirow{2}{*}{$7 \mathrm{t}$} & \multirow{2}{*}{$"$} & \multirow{2}{*}{ " } & 册 & 曲 & 曲 & $\mathrm{H}$ & H & HI & $+t$ & + & + & - \\
\hline & , 體 & & & & & & 册 & 曲 & 册 & H & H & HI & tt & + & + & - \\
\hline & 青頭 & \multirow[b]{2}{*}{$\cdot "$} & \multirow[b]{2}{*}{$"$} & \multirow{2}{*}{$10 \mathrm{t}$} & \multirow[b]{2}{*}{$"$} & \multirow[b]{2}{*}{$"$} & 世 & 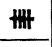 & 少 & 册 & 册. & H & tt & + & + & - \\
\hline \multirow[t]{3}{*}{ 組 } & , 體 & & & & & & 册 & 册 & 册 & $\mathrm{HH}$ & $\mathrm{HH}$ & $\mathrm{H}$ & $t+$ & + & + & - \\
\hline & 紫頭 & & & & & & H & H & m & $\mathrm{HI}$ & $\mathrm{H}$ & $\mathrm{HH}$ & $t+$ & + & + & - \\
\hline & , 體 & $"$ & $"$ & $14 \mathrm{t}$ & $"$ & $"$ & m & 曲 & 曲 & $\mathrm{H}$ & 册 & 世 & $+t$ & + & + & - \\
\hline & 黃頭 & & & & & & 册 & 册 & 册 & 册 & $\mathrm{H}$ & W & Ht & + & + & - \\
\hline & , 體 & $0.01 \mathrm{c} . \mathrm{a}$ & ", & $4 \mathrm{t}$ & $"$ & ", & 無 & 册 & 曲 & 册 & H & W & t+ & + & + & $一$ \\
\hline B & 赤頭 & & & & & & \#II & 册 & 册 & 册 & H & $\mathrm{HH}$ & t+ & + & + & - \\
\hline & , 體 & "' & $"$ & $r \mathrm{t}$ & $"$ & $"$ & 册 & 曲 & mI & HI & $\mathrm{HI}$ & $\mathrm{H}$ & $H$ & + & + & - \\
\hline & 毒頭 & & & $10 t$ & & & 册 & HI & 冊 & HI & $\mathrm{HI}$ & $\mathrm{HH}$ & $+t$ & + & + & - \\
\hline 組 & "體 & $"$ & $"$ & 102 & $"$ & $"$ & m & m & HI & HIt & $\mathrm{H}$ & HI & $t+$ & + & + & - \\
\hline & 紫頭 & & & $14 \mathrm{t}$ & & & 曲 & 册 & 册 & 册 & H & $\mathrm{HH}$ & $+t$ & + & + & - \\
\hline & , 體 & $"$ & $"$ & 146 & $"$ & $"$ & 曲 & 曲 & 册 & 册 & $\mathrm{H}$ & $\mathrm{WH}$ & $t+$ & + & + & - \\
\hline & 黄頭 & & & & & & 册 & m & m & HI & $\mathrm{H}$ & $\mathrm{H}$ & $t+$ & + & + & - \\
\hline & , 體 & $0.1 \mathrm{ca}$ & $"$ & $4 \mathrm{t}$ & $"$ & $"$ & 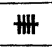 & 册 & HA & 曲 & H & $\mathrm{HI}$ & $t+$ & + & \pm & - \\
\hline C & 赤頭 & & & $7 \mathrm{t}$ & & & 册 & HI & m & 曲 & $\mathrm{H}$ & $\mathrm{HI}$ & $t+$ & + & + & - \\
\hline & , 體 & $"$ & $"$ & $1 \mathrm{c}$ & $"$ & "? & HIt & 删 & $\mathrm{H}$ & 曲 & H & $\mathrm{H}$ & $t+$ & + & + & - \\
\hline & 靑頭 & & & & & & HIt & 曲 & 世 & 册 & H & H & $t+$ & + & - & - \\
\hline 組 & " 體 & $"$ & $"$ & $10 \mathrm{t}$ & $"$ & $"$ & HII & 册 & HI & HI & $\mathrm{HH}$ & HI & $t+$ & + & - & - \\
\hline & 紫頭 & & & $14 \mathrm{t}$ & & & 曲 & 亜 & m & m & $\mathrm{H}$ & $\mathrm{HH}$ & $+t$ & + & - & - \\
\hline & , 體 & $"$ & $"$ & 142 & $"$ & $"$ & 曲 & 世 & 楅 & 曲 & $\mathrm{H}$ & $\mathrm{HI}$ & $t+$ & + & - & - \\
\hline & 黃頭 & & & & & & HII & m & HI & $\mathrm{H}$ & $H$ & $\mathrm{H}$ & $+t$ & + & + & - \\
\hline & , 體 & U.зс.с. & $"$ & $4 \mathrm{t}$ & $"$ & $"$ & 册 & 世l一 & 册 & $\mathrm{HH}$ & $\mathrm{HI}$ & HI & $t+$ & + & + & - \\
\hline D & 赤頭 & & & & & & HIt & m & 册 & $\mathrm{HI}$ & $\mathrm{HI}$ & HI & $t+$ & + & - & - \\
\hline & , 體 & $\because$ & $"$ & $7 \mathrm{t}$ & $"$ & $"$ & HII & HI & 册 & $\mathrm{HI}$ & H & HI & $t+$ & + & - & - \\
\hline & 毒頭 & & & & & & m & 册 & HI & $\mathrm{HI}$ & $\mathrm{H}$ & $\mathrm{HH}$ & + & + & - & - \\
\hline 組 & , 體 & $"$ & $"$ & $10 \mathrm{t}$ & $"$ & $"$ & HII & HII & 册 & $\mathrm{HI}$ & $\mathrm{H}$ & Wl & + & + & - & - \\
\hline & 紫頭 & & & $14 \mathrm{t}$ & & ," & 册 & Hit & mil & $H$ & HI & H & + & - & - & - \\
\hline & , 體 & $"$ & $"$ & 146 & $"$ & $"$ & \#\# & 册 & 册 & $\mathrm{HI}$ & 世 & $\mathrm{HH}$ & + & - & - & - \\
\hline 對 & 黄頭 & 福島培地 & & $14 \mathrm{t}$ & & & 册 & m & 曲 & 曲 & $\mathrm{H}$ & $\mathrm{H}$ & $t+$ & + & + & - \\
\hline 照 & , 體 & & $"$ & $14 \mathrm{t}$ & $"$ & $"$ & mint & 册 & H & 册 & $\mathrm{H}$ & $\mathrm{H}$ & $+t$ & + & + & - \\
\hline 塔 & 赤頭 & & & & & & 曲 & 鉦 & 册 & 曲 & HI & $\mathrm{HI}$ & $t+$ & + & + & - \\
\hline & , 體 & 培 & 占 & 株 & $"$ & $"$ & 册 & 册 & m & m & H & H & $t+$ & + & + & - \\
\hline
\end{tabular}

各 3 列，賽驗 72 列二略示ス 


\begin{tabular}{|c|c|c|c|c|c|c|c|c|c|c|c|c|c|c|c|c|c|c|}
\hline \multirow{2}{*}{\multicolumn{2}{|c|}{ 「マウス」 }} & \multicolumn{5}{|c|}{ 「ワクチン」皮下注射 } & \multirow{2}{*}{\multicolumn{2}{|c|}{$\begin{array}{l}\text { 生活 Lp } \\
\text { 接種 }\end{array}$}} & \multirow{2}{*}{\multicolumn{10}{|c|}{ 腹脉液檢查時日及成樍 }} \\
\hline & & 筍 1 第 & 第 2 回 & & 3 国 & 總 & & & & & & & & & & & & \\
\hline $\begin{array}{l}\text { 組 } \\
\text { 别 }\end{array}$ & 符號 & 量 & 間 量 & 間 & 量 & $\begin{array}{l}\text { 使 } \\
\text { 用 } \\
\text { 量 }\end{array}$ & 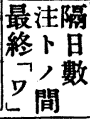 & 量 & $\begin{array}{l}\mathbf{m} \\
\mathbf{3 0}\end{array}$ & $\begin{array}{l}\mathrm{h} \\
2\end{array}$ & $\ddot{4}$ & $\ddot{6}$. & $\ddot{12}$ & $\ddot{24}$ & $\ddot{48}$ & $\begin{array}{l}\mathrm{t} \\
\mathbf{3}\end{array}$ & $\ddot{4}$ & $\ddot{5}$ \\
\hline \multirow{4}{*}{ 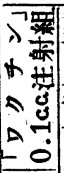 } & \multirow{2}{*}{ 黄頭 } & \multirow{2}{*}{\multicolumn{2}{|c|}{\begin{tabular}{|c|c}
$\mathbf{t}$ & 0.07 \\
7 & c.a
\end{tabular}}} & \multirow{2}{*}{\multicolumn{3}{|c|}{0.}} & \multirow{2}{*}{$14 \mathrm{t}$} & \multirow{2}{*}{$0.3 a c$} & 册 & H+m & H & + & + & \pm & - & - & - & - \\
\hline & & & & & & & & & 册 & 册 & 世 & + & + & + & - & - & - & - \\
\hline & \multirow{2}{*}{\begin{tabular}{|l|} 
毒頭 \\
體
\end{tabular}} & \multirow{2}{*}{$\begin{array}{c}0.01 \\
. .9 \\
\end{array}$} & \multirow{2}{*}{$\begin{array}{ll}0 & 03 \\
c .9\end{array}$} & & \multirow{2}{*}{$\begin{array}{c}0.06 \\
c . c\end{array}$} & \multirow{2}{*}{.1} & \multirow[b]{2}{*}{$"$} & \multirow[b]{2}{*}{$"$} & m & 册 & H & + & + & - & - & - & - & - \\
\hline & & & & & & & & & mith & m & $\mathrm{H}$ & + & + & - & - & - & - & - \\
\hline \multirow{4}{*}{ 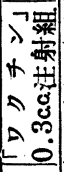 } & \multirow{2}{*}{ 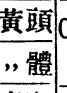 } & 0.1 & \multirow{2}{*}{$\begin{array}{r}0.2 \\
\text { c.G. }\end{array}$} & & \multirow{2}{*}{\multicolumn{2}{|c|}{$\begin{array}{l}0 . \\
c\end{array}$}} & & \multirow[b]{2}{*}{$"$} & 曲 & 册 & W & + & + & - & - & - & - & - \\
\hline & & c.c. 7 & & & & & & & 册 & 冊 & 世 & + & + & - & - & - & - & - \\
\hline & \multirow{4}{*}{ 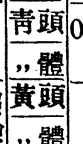 } & & \multirow{2}{*}{\multicolumn{2}{|c|}{\begin{tabular}{r|r}
0.1 & 1 \\
c.a. & 7 \\
\end{tabular}}} & \multirow{3}{*}{\multicolumn{2}{|c|}{\begin{tabular}{c|c|c|c}
$\mathrm{t}$ & 0.15 & 0. \\
7 & $\mathrm{a.c}$ & $\mathrm{c} . \mathrm{c}$ \\
\end{tabular}}} & \multirow{3}{*}{$"$} & \multirow[b]{2}{*}{$"$} & 册 & 册 & $\mathrm{H}$ & + & + & 一 & - & - & - & - \\
\hline & & a.a $\mid 7$ & & & & & & & 册 & 册 & $\mathrm{m}$ & + & + & - & - & - & - & - \\
\hline & & & & & & & & & $\mathrm{tht}$ & HIt & 冊 & 刪 & 曲 & $\mathrm{H}$ & $+t$ & + & + & - \\
\hline & & & 培 & & 宣 & & & & $\mathrm{m}$ & 册 & 册 & $\mathrm{m}$ & m & $\mathrm{H}$ & $1+$ & + & + & - \\
\hline
\end{tabular}

5 列, 賽驗 72 列 $=$ 略示ス

第 73 表

\begin{tabular}{|c|c|c|c|c|c|c|c|c|c|c|c|c|c|c|c|c|c|c|c|}
\hline \multirow{2}{*}{\multicolumn{2}{|c|}{ |マウス」 }} & \multicolumn{6}{|c|}{ 「ワクチン」注射 } & \multirow{3}{*}{ 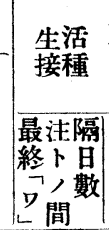 } & \multirow{3}{*}{\begin{tabular}{|l|} 
Lp \\
量 \\
\end{tabular}} & \multirow{2}{*}{\multicolumn{10}{|c|}{ 腹腔液檢査時日及成績 }} \\
\hline & & 第 1 & \multicolumn{2}{|c|}{ 第 2 间 } & \multicolumn{2}{|c|}{ 第 3 国 } & \multirow{2}{*}{\begin{tabular}{l|l}
0 旬 & 總 \\
使 \\
用 \\
量
\end{tabular}} & & & & & & & & & & & & \\
\hline $\begin{array}{l}\text { 組 } \\
\text { 別 }\end{array}$ & 符號 & 量 & 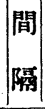 & 量 & 間 & 量 & & & & $\begin{array}{l}\mathbf{m} \\
30\end{array}$ & $\stackrel{\mathrm{h}}{2}$ & $\ddot{4}$ & $\ddot{6}$ & 12 & 24 & $\ddot{48}$ & $\stackrel{\mathrm{t}}{3}$ & 4 & 5 \\
\hline \multirow{3}{*}{$\begin{array}{l}\text { 皮注 } \\
\text { 下射 } \\
\text { 組 }\end{array}$} & \multirow{3}{*}{\begin{tabular}{|l|} 
䫚 \\
體 \\
腎 \\
\end{tabular}} & \multirow{3}{*}{.01} & & \multirow{3}{*}{$\left|\begin{array}{c}0.03 \\
\text { c.c. }\end{array}\right|$} & & \multirow{3}{*}{$\left|\begin{array}{c}0.06 \\
\text { c. }\end{array}\right|$} & \multirow{3}{*}{$\begin{array}{r}0.1 \\
\text { c.c. }\end{array}$} & \multirow{3}{*}{$14 \mathrm{t}$} & \multirow{3}{*}{$\begin{array}{r}0.3 \\
\text { c.c. }\end{array}$} & 册 & 帚 & $H$ & + & + & - & - & - & - & - \\
\hline & & & & & & & & & & 册 & mt & H & + & + & - & - & - & - & 一 \\
\hline & & & & & & & & & & 册 & 册 & WI & + & + & - & - & - & - & - \\
\hline \multirow{3}{*}{$\begin{array}{l}\text { 复注 } \\
\text { 射射 } \\
\text { 苪組 }\end{array}$} & \multirow{3}{*}{\begin{tabular}{|l|}
, 黄頭 \\
, 㹂 \\
\end{tabular}} & \multirow{3}{*}{\multicolumn{2}{|c|}{$\begin{array}{c}.01 \\
\text { c.c. }\end{array}$}} & \multirow{3}{*}{$7 \mid \begin{array}{l}0.9 \\
\text { a. }\end{array}$} & \multirow{3}{*}{$\begin{array}{l}\mathbf{t} \\
7\end{array}$} & \multirow{3}{*}{$\begin{array}{c}0.06 \\
\text { c.c. }\end{array}$} & \multirow{3}{*}{$\begin{array}{l}.1 \\
\text { cc }\end{array}$} & \multirow{3}{*}{$14 \mathrm{t}$} & \multirow{3}{*}{$\begin{array}{r}0.3 \\
\text { c.c. }\end{array}$} & + & + & + & - & - & - & - & - & - & - \\
\hline & & & & & & & & & & + & + & + & - & - & - & - & - & - & - \\
\hline & & & & & & & & & & + & + & + & - & - & - & - & - & - & - \\
\hline \multirow{2}{*}{\multicolumn{2}{|c|}{ 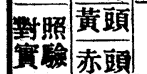 }} & & & & & & & & & 䉼 & 冊 & m & III & 册 & $\mathrm{HI}$ & $\mathrm{Ht}$ & + & - & - \\
\hline & & & & & & & & & & 册 & tht & 曲 & 曲 & 册 & 世 & H & + & - & - \\
\hline
\end{tabular}

各 10 列, 實驗 73 列二略示

二對シ「ワクチン」0.1c.c一-0.3c.. キ皮下二唯 1 回注射シタル場合ニハ 10-14 日後二至 レバ腹腔內二接種セル Lp キシテ對照無處置「マウス」ニ於ケルョリモ゙ 24 時間早ク死 堿融解七シムルチ知リタリ。上記「ワクチン」量タ 2 包二分割注射シタル場合ト 3 回ト 二注射シタル場合トチ比較シ兩者二於ケル免疫發現ノ强弱于觀察セリ。注射ノ間隔ハ 何レモ 7 日間卜定メテ實駷セリ。其成績ハ第 72 表ノ如ク（1）「ワクチン」0.1ca注 射「マウス」-2回分割注射組二於テハ腹腙內二接種七ル $\mathrm{Lp}$ /生活時間ハ 24 時間 3 回分割注射組二於テハ12時間。(2)「ワクチン」0.3c.c. 注射「マウス」一2回分割注 
射組ハ 12 時間. 3 回分割注射組ハ 4 時間。以上ノ如ク「ワクチン」ノ一定量チ 2 回二分 割注射スルョリモ $\mathbf{3}$ 回二分割注射スル場合二於テ免疫ノ發現八强度ナルチ知リタリ。

II.「ワクチン」注射部位チ異二セル場合：「ワクチン」注射「マウス」ニ於ケル免废發 現ノ觀察ハ。該「マウス」腹腔夜內二於ケル $\mathrm{Lp}$ ノ生活時間き對照賽瑍ノ夫レト比較シ テ決定スルガ故ニ「ワクチン」キ皮下二注射シタル場合ト．腹腔內二注射シタル場合ト ニョリ.免疫ノ發現二相異キ示スヤ否ヤキ檢シタリ。其成績第 73 表ノ如ク. 皮下二注 射シタル場合ハ. $\mathrm{Lp}$ ／生活時間ハ 12 時間ナル二對シ。腹腔內二注射シタル場合ハ。 僅カ $=4$ 時間ノミ生活スルチ認メタリ。郎チ兩者二於ケル免疫發現ノ强弱二格段ノ相 異アルキ認メタリ。

\section{第二節 腹腔內ニ「ワクチン」ヨ泩射セル場合ニ於ケル}

\section{免疫性ノ發現時間二就テ}

「ワクチン」キ腹腔內二注射七几場合二於ケル㤫疫性ノ發現時間キ追及ス可ク以下， 實驗キ行へリ。實驗方法：體重 $10 \mathrm{~g}$ ノ「マウス」チ 3 群二分チ。各群キ更二 7 組二區 別シ。 1 組ノ實驗二對シ 3 正ノ「マウス」キ用意シ。「ワクチン」量ハ何レモ0.1caト一 定シ。第 1 群二八全使用量于 1 回二。第 2 群二ハ 2 回二分割. 第 3 群二ハ 3 包二分割 注射ス。分割注射, 間隔ハ 1 日ヨリ7 日二至ル各日數チ以テシ。最終「ワクチン」注射 ト病原 $\operatorname{Lp}$ 接種マデ，間隔ハ。1日ョリ7日ニ至ル各日數キ以テシ。爾後時間的二腹

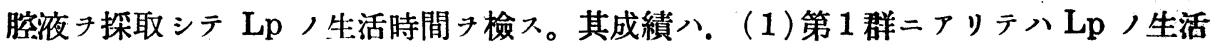
時間ハ對照實驗ト相違キ見ズ。（2）第 2 群ニ於テハ「ワクチン」注射間隔 1-3 日間病 原 Lp 接種間隔 1-3 日(最終「ワクチン」注射ヨリ)ノモノ八. 對照實驗ト同一ニシテ免 疫現象發現七ズ. 間隔 4-5 日ノモノハ $\mathrm{Lp}$ 人生活時間ハ 3 日間ニシテ對照筫驗 $ョ$ 24 時間早ク死隇融解スルチ認メ。6-7 日ノモノニアリテハ Lp 生活時間ハ 12 時間二 シテ對照ョリ 60 時間早ク $\mathrm{Lp}$ 人死隇融解スルチ認メタリ。（3）第 3 群二於テ’八 1-2 日間隔ノモノハ免疫現象發現七ズ. 3 日ノモノハ $\mathrm{Lp}$ 生活時間ハ 48 時間ニシテ 對照二比シ 48 時間早ク $\mathrm{Lp}$ ノ死滅融解スルタ認メ.4-7 日ノモノハ $\mathrm{Lp}$ ，生活時間

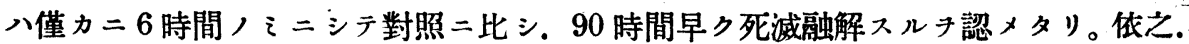
免疫現象／發現時間ハ「ワクチン」キ 3 回二分割的二注射シ。其間隔ハ 4-7 日ノモ， 二於テ發現時間最モ早ク且ッ强度ナルチ認メタリ(實驗表省略)。

\section{第三節 能働性免疫賦與「マウス」ノ免疫成立 ヨ確證スル實驗}


免度賦與「マウス」ガ腹檫內二接種シタル Lp チ速二死咸融解七シムルハ上述ノ如シ 如斯半 Lp 死隇融解現象ハ果シテ「マウス」ノ免疫成立標示ト看做シ得ルヤ否ヤ郎于 免疫成立ノ確證ナルヤ否ヤキ立證セント欲シ. 以下ノ如ク免疫賦與「マウス」腹腔內二

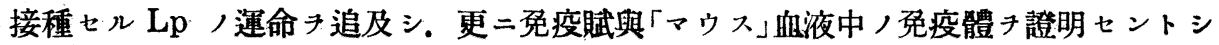
タリ。

\section{第一項 免疼賦與「マウス」腹望內二接種セル Ip ノ迺命}

體重 $10 \mathrm{~g}$ ノ「ウス」ニ「ワクチン」量 $0.1 \mathrm{cc}$ × 7 日ノ間隔チ以テ 3 回二皮下二注射 シ. 最後ノ注射後第 14 日二於テ該「マウス」腹腔內二Lp 培養 $0.3 \mathrm{ca}$ 丹接種シ. 爾後

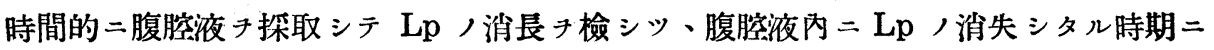

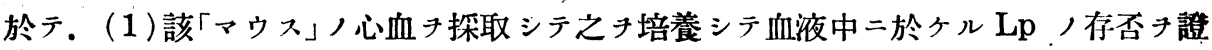
明スルト同時二。(2)該「マウス」ノ肝臟。筒臟。脾藏。淋巴腺キ剔リテ浮游液キ製シ

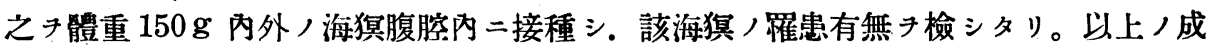
績ハ心血キ採取培養シタルモ Lp キ證明シ得ズ. 肝臟. 腎藏. 脾藏及淋巴腺キ海猽二 接種シタル賽驗二於テモ罹患キ認メザリキ。以上ニヨリ免疫賦與「マウス」腹檫內二接 種シタル $\mathrm{Lp}$ ，運命ハ, 腹腔内二於テ速カ二死隇融解シ。血液中立的藏器中二出現 ルコトナキチ知リタリ。

\section{第二項 龟疫賦與「マウス」血清中二於ヶル免疫體ノ證明}

\begin{tabular}{|c|c|c|c|c|c|c|c|c|c|c|c|c|c|c|c|}
\hline \multirow{3}{*}{ 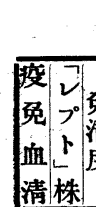 } & & & & 第 & & & & & & & & & & & \\
\hline & & 稀釋シ可 掼 & $v^{2}$ 株 & $\sqrt{1}$ & 䇤 & \multicolumn{10}{|c|}{ 腹腔液檢查時日及成績 } \\
\hline & 清䅧 & 清量 血 混入 & 且 & 腔注入 & $\left|\begin{array}{l}\dot{n} \\
z^{2} \\
\text { 號 }\end{array}\right|$ & $\begin{array}{l}\mathrm{m} \\
30\end{array}$ & $\frac{\mathrm{h}}{2}$ & $\ddot{4}$ & $\ddot{6}$ & $\ddot{12}$ & $\ddot{24}$ & $\ddot{48}$ & $\begin{array}{l}\mathrm{t} \\
3\end{array}$ & $\ddot{4}$ & $\ddot{5}$ \\
\hline \multirow{14}{*}{ 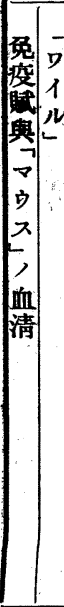 } & 10 & $\frac{1}{1 . c . c+1 . c . a}$ & 20 & $0.6 \rightarrow$ & |黃頭 & - & - & - & - & - & - & - & - & - & - \\
\hline & 20 & $n+n$ & 40 & & ,體 & - & - & - & - & - & - & - & - & - & - \\
\hline & 40 & $"+n$ & 80 & “ $\rightarrow$ & , 腎 & - & - & - & - & - & - & - & - & - & - \\
\hline & 80 & $"+n$ & 160 & $\ddot{\prime \prime}$ & 青頭 & - & - & - & - & - & - & - & - & - & - \\
\hline & 160 & $"+$ & 320 & $" \rightarrow$ & , 體 & + & - & - & - & - & - & - & - & - & - \\
\hline & 320 & $\ldots+\ldots$ & 640 & 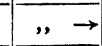 & ”腎 & + & - & - & - & - & - & - & - & - & - \\
\hline & 640 & $"+$, & 1280 & $\bar{n}$ & 赤頭 & + & - & - & - & - & - & - & - & - & - \\
\hline & 1280 & $"+$, & 2560 & 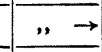 & , 體 & + & - & - & - & - & - & - & - & - & - \\
\hline & 2560 & $"+n$ & 5120 & $\ddot{\rightarrow}$ & 督 & + & + & - & - & $\div$ & - & - & - & - & - \\
\hline & 5120 & $"+$ & 10244 & $" \rightarrow$ & 紫頭 & + & + & + & + & + & + & + & + & + & - \\
\hline & 10240 & $"+$ & 20480 & 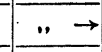 & , 體 & + & + & + & + & + & + & + & + & + & - \\
\hline & 20480 & $"+$ & $\overline{40960}$ & 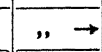 & ; 腎 & + & + & + & + & + & + & + & + & + & - \\
\hline & 對照 & 培 & 株 & $\begin{array}{r}0.25 \\
\mathrm{aG} \rightarrow\end{array}$ & 手 & 冊 & 册 & "Wl & 曲 & 册 & H & H & + & + & - \\
\hline & 貫駼 & & & & , 足 & 册 & 册 & $\mathrm{III}$ & 曲 & 刪 & \# & + & + & + & - \\
\hline
\end{tabular}




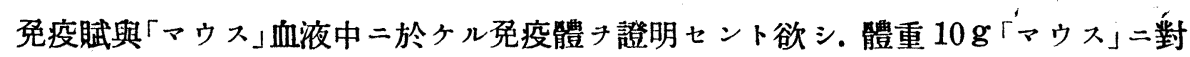
シ「ワクチン」0.1c.c.チ 7 日ノ間隔キ以テ 3 回二分割注射シ。最終注射後 2 週キ經テ心 血キ採取血清キ分離シ。本血清キ以テ「マウス」腹膑內溶菌反應キ檢シタリ。(第 74 表〉 實驗 30 分ニシテ 160 倍. 2 時間ニシテ 560 倍. 4 時間ニシテ 5120 倍二於テ陽性き呈， ス。郎于免疫賦與「マウス」血清中二免疫體キ證明スルチ得タリ。以上本節第一項及第

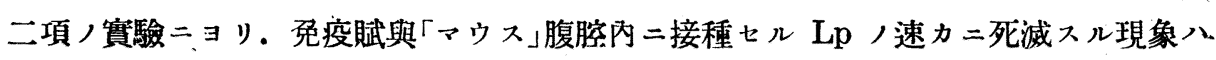
該「マウス」/能働性㣻疫成立丹立證スルニ足ル。

\section{第三章「ワクチン」ノ抗原價測定法ニ關スルー考寀}

Lp「ワクチン」抗原價ハ「ワクチン」製作二用ヒタル Lp 株ノ毒力强弱. Lp 數ノ多

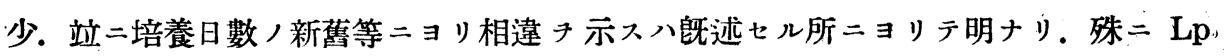
培養條件, 適否八直 $=\mathrm{Lp}$ ，發有良否丹招來スルノiナラズ. ソノ毒力二モ重大ノ, 影䍹キ及ボスキ以テＬL「「クチン」ノ製作ニハ他ノ一般細菌「ワクチン」ノ製作二此: シ一層ノ努力ト熟練ト丹要入。從來 Lp「ワクチン」ノ抗原價ノ强弱キ檢スルニハ海猽 キ用ヒソノ體重二應ジ。種々異ナル「ワクチン」量キ試驗的二注射シ。動物ガ病原體二 對シ感染キ防禦シ得ルニ至リタル「ワクチン」ノ最少用量キ以テ力價キ定メタリ。余ハ. 從來ノ「ワクチン」ノ抗原價测定法二八. 上記ノ如ク不備. 不便ノ點アルチ感沪次ノ如: キ改良法チ考案セリ。郎チ「ワクチン」テ遽次的二稀釋シ・ソノ一定量キ 3 回二分割シ 4 日ノ間隔キ以テ「マウス」腹腔內二注射シ。最後ノ注射ヨリ 4 日チ經テ $\mathrm{Lp}$ 培養キ接 種シ. 爾後腹腔液キ時間的二探取检查シテ. Lp /死隇融解スルチ檢入。本方法ハ「ウ クチン」ノ抗原價キ定量的二测定スルノミナラズ. 12-15 日間二成績キ制定シ得ルガ 故二從來ノ方法二比較スレバ賔驗所要日數丹著シク短縮シ且.定量的二測定シ得ル便。 湓大ナリ。

\section{第一節 測定法ノ賽驗的基礎}

本測定法ノ實驗的基礎ハ以下述ブルガ如ク．A．實驗動物ノ「マウス」ニ關 シテハ. (1) 能働性免疫賦與「マウス」八腹腔內二接種七ル病原 Lp チ速カ二死隇融解七シメ. (2)ソノ死隇融解現象ハ「「ウス」ノ免疫成立キ表徵スルモノナルコトキ立證シ. (3) Lp；死滅融解現象ノ發現ハ「ワクチン」チ皮下二注射七ル場合ョリモ. 腹腔内 注射七几場合二於テ强度且ツ速カナリ。(4)「ワクチン」腹腔內二注射セル場合二於 ケル免度現象發現＼cjkstart强度ハ「ワクチン」ノ一定量チ 4 日以上 7 日間，間隔チ以テ 3 回二 


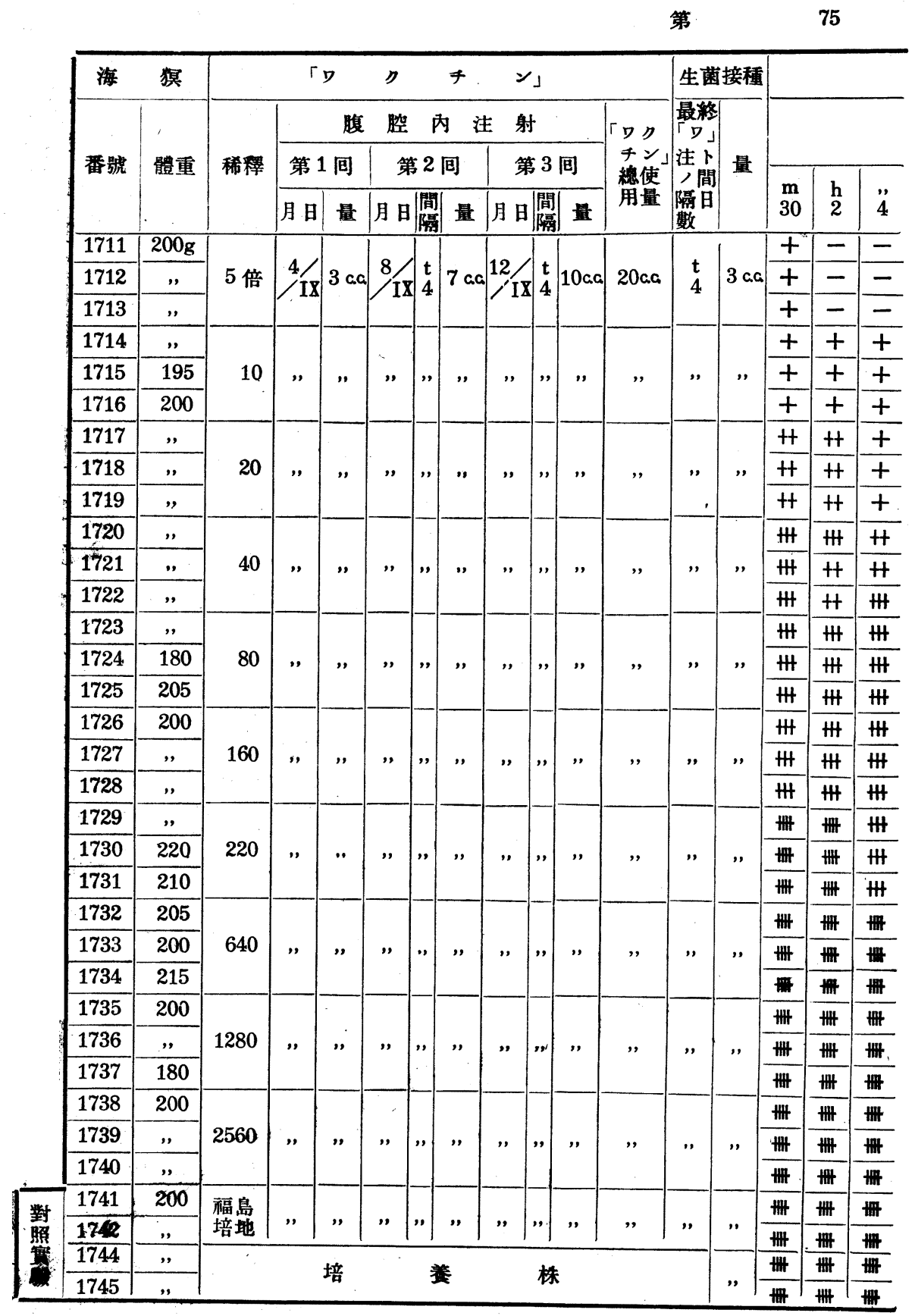

3 列 / 對照實臉 72 列 =略示ス 
表

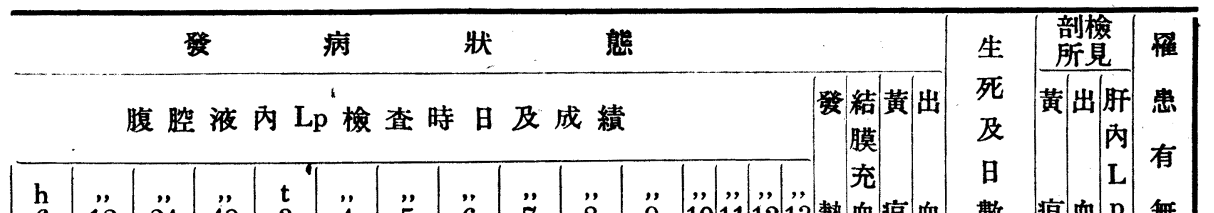

\begin{tabular}{|c|c|c|c|c|c|c|c|c|c|c|c|c|c|c|c|c|c|c|c|}
\hline 6 & 12 & 24 & 48 & 3 & 4 & 5 & 6 & 7 & 8 & $\ddot{9}$ & $\ddot{10}$ & & & & & & 數 & 百 $\mathbf{m}$ & 無 \\
\hline- & - & - & - & - & - & - & - & - & - & - & $=$ & & & $t=$ & $=$ & & 生 & & - \\
\hline - & - & - & - & - & - & 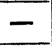 & - & - & - & - & & & & - & $=$ & - & $"$ & & - \\
\hline- & - & - & - & 死 & & & & & & & & & & & $=$ & & 死 $3 \mathrm{t}$ & & - \\
\hline- & - & - & - & - & - & - & - & - & - & - & & & & $=$ & -7 & & 生 & & - \\
\hline- & - & - & - & - & - & - & - & - & - & - & 二 & & & $=$ & $=$ & - & , & & - \\
\hline- & - & - & - & - & - & - & - & - & - & - & & & & $=$ & $=$ & - & , & & - \\
\hline+ & - & - & - & - & 死 & & & & & & & & & $=$ & $=$ & - & 死 & & - \\
\hline \pm & - & - & - & - & - & - & - & - & - & - & 二 & & & $=$ & $=$ & 二 & 生 & & - \\
\hline+ & - & - & - & - & - & - & - & - & - & - & & - & & $=$ & 二 & 二 & ", & & - \\
\hline H+ & + & + & - & - & - & - & - & 一 & - & - & Z & & & - & - & 二 & , & & - \\
\hline H & + & + & - & - & - & - & - & - & - & - & & - & & $=$ & 二 & $=$ & , & & - \\
\hline$H$ & + & + & - & - & - & - & - & - & - & - & 二 & E & & $=$ & & 二 & , & & - \\
\hline H & $H$ & $+t$ & + & - & - & - & - & - & - & - & 二 & & & $=-$ & 二 & - & , & & - \\
\hline 册 & $+t$ & ++ & + & - & - & - & - & - & - & - & 二 & & & $=$ & $=$ & $=$ & , & & - \\
\hline t+ & $H$ & $H$ & + & - & - & - & - & - & - & - & 二 & - & 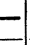 & $=-$ & $=$ & - & $"$ & & - \\
\hline $\mathrm{HH}$ & t+ & + & + & + & - & - & - & - & - & - & & & & $=-$ & 二 & $\square$ & , & & - \\
\hline HI & $H$ & $+t$ & + & + & - & - & - & - & - & - & 二 & & & $=$ & $=$ & 二 & ", & & - \\
\hline m & $+t$ & $H$ & + & + & - & - & - & - & - & - & $=$ & - & - & $=$ & $=$ & 二 & , & & - \\
\hline H & m & ++ & + & + & + & + & - & - & - & - & $=$ & $=$ & & $=$ & 二 & - & ", & & - \\
\hline HI & $H$ & + & + & - & - & - & - & - & - & - & $=$ & & & \pm \pm & \pm & 二 & , & & \pm \\
\hline m & $\mathrm{Ht}$ & $H$ & + & \pm & + & + & + & - & - & - & $=$ & = & & $=$ & 二 & - & , & & - \\
\hline $\mathrm{WH}$ & H & + & + & + & + & + & + & - & - & - & $=$ & $=$ & & \pm \pm & + & 二 & , & & + \\
\hline H & $\mathrm{HH}$ & $+t$ & + & + & + & + & + & $+t$ & $+t$ & $H$ & \pm & 死 & & \pm \pm & III & + & 死12 t & HIIII & + \\
\hline m & H & $+t$ & + & + & + & + & + & + & + & ++ & m & 死 & & + \pm & 册 & \pm & $" 12$, & IIIII & + \\
\hline 册 & H & $+t$ & Ht & $H$ & t+ & ++ & H & H & H & 死 & & & & & m & 二 & 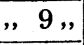 & $H \pm \pm$ & + \\
\hline m & HI & $t+$ & H+ & H+ & $+t$ & $+t$ & t+ & H & $t+$ & $+t$ & 死 & & & \pm \pm & m & + &, 10, & $\mathrm{H}=\mathrm{H}$ & + \\
\hline 册 & $\mathrm{H}$ & 死 & & & & & & & & & & & & & & & & $=-$ & 不明 \\
\hline 無 & H & $\mathrm{H}$ & $\mathrm{H}$ & H & H & t & 死 & & & & & & & & \# & + & $" 6$, & mI \pm & + \\
\hline 册 & H & $\mathrm{HH}$ & $\mathrm{H}$ & HI & $\mathrm{H}$ & H & $H$ & H+ & 死 & & & & & \pm \pm & WI & &, 8, & \#\# & + \\
\hline 册 & H & $\mathrm{HH}$ & $\mathrm{H}$ & $\mathrm{H}$ & $\mathrm{HH}$ & t+ & $t+$ & H & 死 & & & & & \pm+ & \# & + & $" 8$, & IIII & + \\
\hline m & 册 & $\mathrm{H}$ & 世 & $\mathrm{H}$ & $\mathrm{H}$ & 册 & 死 & & & & & & & \pm \pm & m & \pm & $" 6$, & $\mathrm{m}$ $\mathrm{H}$ & + \\
\hline m & m & 世 & $\mathrm{H}$ & m & $\mathrm{H}$ & 死 & & & & & & & & \pm & In & & 5,5 & 曲 & + \\
\hline 册 & 無 & 册 & HI & HI & H & 册 & H & & & & & & & \pm \pm & III & \pm & 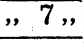 & $\mathrm{WH}$ & + \\
\hline m & 曲 & 亜 & $\mathrm{H}$ & 世 & 曲 & 亜 & 死 & & & & & & & +1 & Im & \pm & $\# 6$, & $\mathrm{HAl} \mathrm{mln}$ & + \\
\hline
\end{tabular}


分割注射スル場合二於テ. 最モ强ク且ツ夫レ等間隔日數ノ相違二不關同一ノ成績テ以 テ發現スルキ認メ。（5）最終「ワクチン」注射後。病原 Lp キ接種スル迄ノ間隔モ亦 4 -7 日二於テ. Lp ノ死滅融解現象八何レモ同一成績キ認メ。

B.「ワクチン」量二關シテハ. 體重 $10 \mathrm{~g} ノ$ 「マス」二對シテ注射部位ノ皮下ナル ト、腹腔內ナルトチ問ハズ「ワクチン」0.1c.c, チ以テ確實二免疫キ成立セシムルチ知リ タルチ以テ. 本「ワクチン」ノ0.1c.a 基礎的用量ト見做シタリ。然レドモ本測定法， 「ワクチン」稀释方法ハ便宜上 5 倍液 1 c.c. (郎チ「ワクチン」含有量 $0.2 \mathrm{ccc}$ ) チ基準トシ.

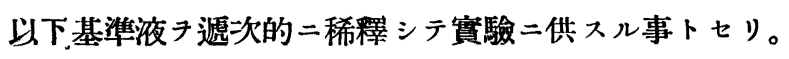

\section{第二節 測定法ノ實驗方式}

(1) 免疫 成立ガ實驗動物,體重站二個性ニョリテ成績ニ相違テ示スナキャチ顧慮 シ. 純ドイッ系白色「マウス」體重 $10 \mathrm{~g}$ ノモノチ選定使用シタリ。（2)「ワクチン 隇菌生理的食監水二テ稀释シ。ソノ各々チ第 1 回ハ 0.15 c.c. 第 2 回ハ 0.35 c.c. 第 3 包ハ 0.5 c.c. $\ni .4$ 日儿間隔キ以テ「マウス」腹腔內二注射入。(3)最終「ワクチン」注射

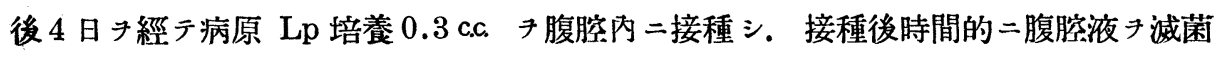
硝子毛細管キ以テ採取シ. Lp ノ死隇融解現象テ檢入。（4)對照實驗ノ第 1 群ハ. 培 地ソノモノチ稀釋「ワクチン」夜ト同一量及同一方法キ以テ注射シタル後同一間隔キ以 テ病原 Lp キ接種シ。他ノ 1 群八健康「マウス」二病原 Lp /同一量キ接種シ。爾後時 間的二腹腔液キ採取シテ Lp ノ生活態度キ檢ス。以上ガ法キ以テ實驗シタル成績ハ 「ワクチン」稀释度 5 倍ハ 2 時間ニシテ Lp チ死隇融解セシメ。10-20 倍ハ 6 時間. 40 -80 倍ハ 24 時間. 160 倍ハ 48 時間. 320 倍ハ 3 日間. 640 倍以上ハ對照實驗ノソ レト等シク Lp，死隇融解現象二相異チ見ズ (第 72 表參照)。

\section{第三節 本測定法ニヨル溶菌值ト免疫海猽ノ威染防禦}

\section{試驗成績トノ比較}

本測定法キ以テシタル溶菌值ハ。能働性免疫き賦與シタル海猽, 感染防禦試驗,成 績ト。如何ナル相關的ノ結果キ示スャチ檢セントシタリ。實驗方法一一體重 $200 \mathrm{~g}$ ， 海猽チ選ビテ實驗ニ供シ「ワクチン」ハ「マウス」ニ比シ 20 倍テ使用セリ.而シテ第 1 回 注射八稀程液 3 c.c. 第 2 回 7 c.c. 第 3 回 10c.a キ何レモ 4 日 間隔二以テ腹腔内二注 射シ. 最終「ワクチン」注射後 4 日チ經テ腹腔內 $=\operatorname{Lp}$ 培養キ接種 $3 \mathrm{cca}$ シ. 爾後腹腔內 Lp /消長立二海猽ノ發病狀態キ觀察セリ．對照試驗トシテ第 1 群八培地ソノモノき 
稀释「ワクチン」夜ト同一量及同一方法キ以テ注射シタル後チ同一間隔チ以テ Lp培養

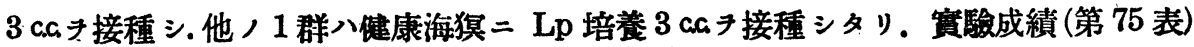
「ワクチン」稀释液 5一10 倍二於テ八寶媛後 2 時間. 20 倍 6 時間. 40 倍 12 時間. 80 160 倍 48 時間ニシテ Lp 八死隇融解シ且ツ感染テ防禦シタリ。320倍ニ於ケル實駿海 獏 3 頭中 1 頭八定型的症狀キ呈シテ 13 日ニシテ擎死シ. . 2 頭八腹腔液內二6 日間 Lp ヲ證明シ且ツ轅度ノ結膜充血. 發熱。黃疸き發現シタルモ健康二復シ。6 640 倍二於テ 八 3 頭中 2 頭ハ定型的症狀ノ下ニ12 日ニシテ獘死シ 1 頭ハ感染き免レタリ。1280 倍

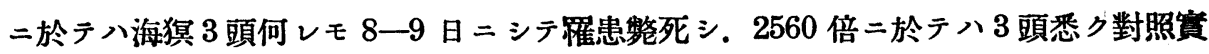
媛ノソント同一日數二於テ斃死シタリ。以上ノ如ク感染防禦率ヨリ見ルニ「ワクチン」 稀程 5一-320 倍ノモノ八病原 Lp 二對シ 100\%二於テ. 640 倍ノモノハ $33 \%$ 二於テ防禦 シ得. 1280 倍ノモノ八海猽ノ致死日數キ $1-2$ 日間延長七シムルノ シ得ズ. 2560 倍ノモノ八對照實驗ト同一成績キ示シテ「ワクチン」處置ノ效果全クナシ 上記海猽感染防禦試驗成績き。「マウス」キ以テスル測定法ノ示ス溶菌値ト比較スレバ

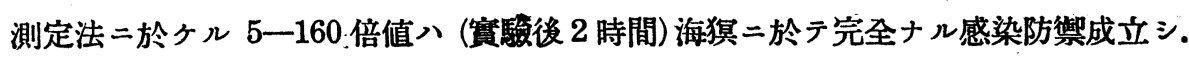
$320-640$ 倍值八 (實驗後 48-72 時間) 海獏二於テ $33 \%$ / i 感染防禦シ. 1280 倍值以上 八何レモ感染防禦成立セズ. 而シテ「マウス」キ以テスル測定法溶菌值ト。海猽き以テ シタル溶菌値トキ比較スル二兩者何レモ同一/溶菌値キ示ス。以上成績キ基本トシテ 本測法定ノ溶菌時間キ海猽ノ成染防禦成績卜比較スルニ。測定法二於ケル 2-48 時間 二於ケル溶菌值ハ。海猽二於テ $100 \%$ 於テ感染防禦成立シ. 72 時間 /溶菌値ハ 33 \%ノ、防禦成立スルチ見ル。 